\title{
Landscape analysis of pre-eclampsia/eclampsia in Nigeria
}

\author{
Charlotte E. Warren \\ Population Council \\ Salisu Mohammed Ishaku \\ Population Council \\ Ayodeji Oginni \\ Gloria Adoyi \\ Population Council \\ Karen Kirk \\ Population Council
}

See next page for additional authors

Follow this and additional works at: https://knowledgecommons.popcouncil.org/departments_sbsr-rh

Part of the Demography, Population, and Ecology Commons, Family, Life Course, and Society Commons, International Public Health Commons, Maternal and Child Health Commons, and the Women's Health Commons

How does access to this work benefit you? Let us know!

\section{Recommended Citation}

Warren, Charlotte E., Salisu Mohammed Ishaku, Ayodeji Oginni, Gloria Adoyi, Karen Kirk, and Amy Dempsey. 2015. "Landscape analysis of pre-eclampsia/eclampsia in Nigeria," Ending Eclampsia Landscape Report. Washington, DC: Population Council. 
Authors

Charlotte E. Warren, Salisu Mohammed Ishaku, Ayodeji Oginni, Gloria Adoyi, Karen Kirk, and Amy Dempsey 


\section{ENDING Eclampsia}

\section{LANDSCAPE ANALYSIS OF PRE-ECLAMPSIA/ ECLAMPSIA IN NIGERIA}

Charlotte Warren

Salisu Ishaku Ayodeji Oginni Gloria Adoyi Karen R. Kirk Amy Dempsey

December 2015 


\section{ENDING}

Ending Eclampsia seeks to expand access to proven, under-utilized interventions and commodities for the prevention, early detection, and treatment of pre-eclampsia and eclampsia and strengthen global partnerships.

\section{POPULATION 7 COUNCIL \\ Ideas. Evidence. Impact.}

The Population Council confronts critical health and development issues-from stopping the spread of HIV to improving reproductive health and ensuring that young people lead full and productive lives. Through biomedical, social science, and public health research in 50 countries, we work with our partners to deliver solutions that lead to more effective policies, programs, and technologies that improve lives around the world. Established in 1952 and headquartered in New York, the Council is a nongovernmental, nonprofit organization governed by an international board of trustees.

Population Council

4301 Connecticut Avenue NW, \#280

Washington DC, 20008

Tel: +1.877 .237 .9400$

www.popcouncil.org

Population Council

House 4, Number 16. Mafeni Crescent, Utako,

Abuja, Federal Capital Territory, 900108

Nigeria.

Tel: +234 (0) 92914878

email: Nigeria@popcouncil.org

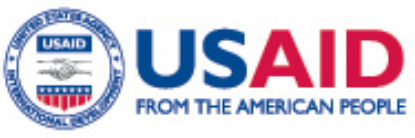

The Ending Eclampsia project is made possible by the generous support of the American people through the United States Agency for International Development (USAID) under the terms of USAID APS-OAA-13-000005. The contents of this report are the sole responsibility of the Ending Eclampsia project and the Population Council and do not necessarily reflect the views of USAID or the United States Government.

Suggested citation: Charlotte Warren, Salisu Ishaku, Ayodeji B. Oginni, Gloria Adoyi, Karen R. Kirk \& Amy Dempsey (2015). Landscaping analysis for pre-eclampsia and eclampsia in Nigeria, Abuja: Federal Capital Territory: Population Council. 


\section{Table of Contents}

Table of Contents ........................................................................................................ iii

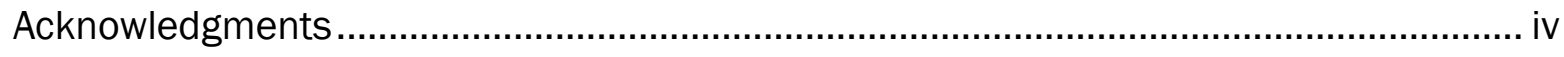

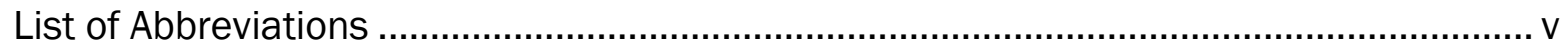

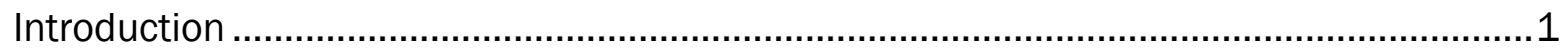

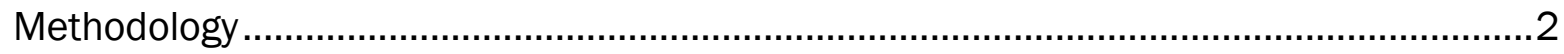

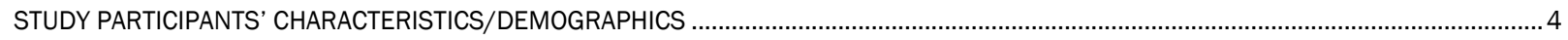

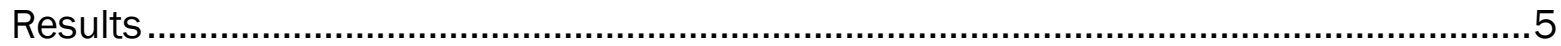

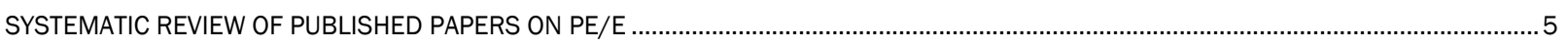

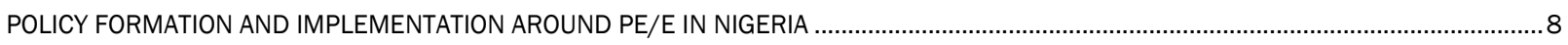

DONOR/PARTNER PROGRAMMATIC SUPPORT FOR MATERNAL AND NEWBORN HEALTH IN NIGERIA ..................................................10

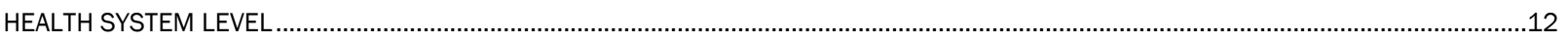

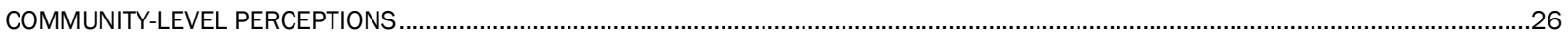

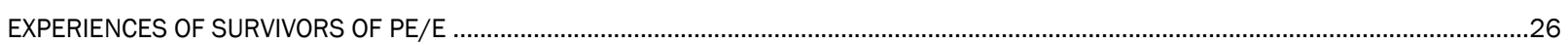

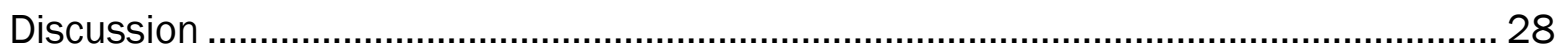

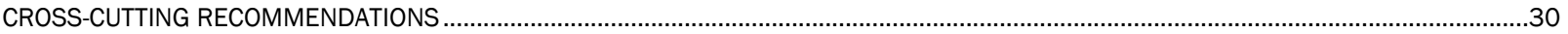




\section{Acknowledgments}

This report is based on a landscape analysis which aimed to ascertain the level of policy, programmatic and facility-based support and preparedness on prevention, detection and management of preeclampsia and eclampsia in Nigeria. The study was conducted in collaboration with the Ministries of Health in Bauchi, Cross River, Ebonyi, Katsina, Kogi, Ondo and Sokoto states.

We acknowledge all stakeholders (government, private and non-profit agencies) and individuals (Joseph Monehin and Emily Hillman) who provided valuable inputs in the design and/or implementation of the project. The successful completion of the study would not have been possible without the dedication of service providers in the participating health facilities. We further acknowledge all the study participants, who gave up their time and provided valuable information during the course of the study. 


\section{List of Abbreviations}

$\begin{array}{ll}\text { ANC } & \text { Antenatal care } \\ \text { BP } & \text { Blood pressure } \\ \text { CHEWs } & \text { Community health extension workers } \\ \text { CHOs } & \text { Community health officers } \\ \text { CHWs } & \text { Community health workers } \\ \text { CPI } & \text { Client-provider interaction } \\ \text { CS } & \text { Caesarean section } \\ \text { EML } & \text { Essential medicines list } \\ \text { EmONC } & \text { Emergency obstetric and newborn care } \\ \text { FGDs } & \text { Focus group discussions } \\ \text { FIGO } & \text { International Federation of Gynecology and Obstetrics } \\ \text { FMoH } & \text { Federal Ministry of Health } \\ \text { HELLP } & \text { Hemolysis, Elevated Liver enzymes, Low Platelet count } \\ \text { IDIS } & \text { In-depth interviews } \\ \text { IDRC } & \text { International Development Research Centre } \\ \text { IRB } & \text { Institutional review board } \\ \text { MCH } & \text { Maternal and child health } \\ \text { MeSH } & \text { Medical subject headings } \\ \text { MgSO } 4 & \text { Magnesium sulphate } \\ \text { mmHg } & \text { Millimeters of mercury } \\ \text { MMR } & \text { Maternal mortality rate } \\ \text { MNH } & \text { Maternal and newborn health } \\ \text { NGOs } & \text { Non-govermental organization } \\ \text { NHREC } & \text { National Health Research Ethic Committee } \\ \text { Ob/Gyn } & \text { Obstetrician and gynecologist } \\ \text { PE/E } & \text { Pre-eclampsia/eclampsia } \\ \text { PHC } & \text { Primary health care } \\ \text { PPH } & \text { Postpartum hemorrhage } \\ \text { RMNCH } & \text { Reproductive, maternal, newborn and child health } \\ \text { SERVICOM } & \text { Service Compact with all Nigerians } \\ \text { SES } & \text { Socio-economic status } \\ \text { SMOs } & \text { Severe maternal outcomes } \\ \text { SOGON } & \text { Society of Gynaecology \& Obstetrics of Nigeria } \\ \text { SPE } & \text { Severe Pre-eclampsia } \\ \text { TBAs } & \text { Traditional birth attendants } \\ \text { UN } & \text { United Nations } \\ \text { USAID } & \text { United States Agency for International Development } \\ \text { WHO } & \text { World Health Organization } \\ & \end{array}$




\section{Introduction}

Despite a $45 \%$ reduction in maternal deaths over the past two decades, about 800 women still die daily from pregnancy-related complications that are largely preventable, with $99 \%$ of these deaths occurring in low- and middle-income countries (World Health Organization, 2015). In Nigeria, as in many developing countries, pre-eclampsia and eclampsia (PE/E), and postpartum hemorrhage (PPH) account for about 50\% of maternal deaths. A recent maternal death and near-miss surveillance in Nigeria confirmed this fact, with new findings indicating that PE/E is now the leading direct cause of maternal mortality in health facilities. In this study (Oladapo et al. 2015), PE/E and PPH accounted for $23.4 \%$ and $14.4 \%$ of severe maternal outcomes (SMOs), respectively.

Through the Ending Eclampsia project, with support from USAID, Population Council is seeking to expand access to proven, underutilized interventions and commodities for the prevention, early detection, and treatment of PE/E and strengthen global partnerships. In order to appreciate the enormity of the problem at country level, the Council conducted a landscape analysis on PE/E in Nigeria between April and September 2015. The main objectives of the landscape analysis were:

- To understand the level of programmatic and policy support for PE/E prevention and treatment;

- To analyze the gaps in providers' competence to prevent, detect, and manage PE/E;

- To determine the capacity at primary health facilities to manage PE/E;

- To assess community awareness, beliefs, and experiences around PE/E;

- To understand the volume of research conducted on PE/E in the last 15 years; and

- To determine priority areas for research and programmatic interventions around PE/E.

In summary, the Council collected data on information around policy support for PE/E, the current program elements addressing PE/E in the country, the capacity of antenatal and maternity care facilities to detect and manage $\mathrm{PE} / \mathrm{E}$, the availability of essential tools and lives-saving commodities at health facilities, the communities' beliefs and misperceptions that hinder pregnant women from receiving timely care, and research gaps to improve health care related to prevention and management of PE/E. This report provides major highlights of the landscape analysis in Nigeria and suggests priority areas for interventions. The report is presented in three thematic areas: policy, health system, and community level. 


\section{Methodology}

The study was cross sectional and encompasses a systematic review of existing grey and published literature, and primary data collection from a range of actors using both qualitative and quantitative methods. For the systematic review, researchers analyzed all published literature on PE/E from 2000 to 2015. For policy and program data at national and state levels, researchers interviewed representatives of policy makers, managers of maternal and newborn health programs, and heads of local and international NGOs. Health facilities in each state were selected from all three senatorial zones. At each study facility, the Council interviewed providers who worked in antenatal, maternity, or labor/delivery wards. Researchers also conducted facility inventories and observed client-provider interactions of ANC consultations prior to interviewing the same pregnant women leaving the facility. Women (18-49 years) and men (18-55 years) participated in focus group discussions (FGDs) to provide a deeper understanding of knowledge and perceptions of $\mathrm{PE} / \mathrm{E}$ and health-seeking pathways of the local community members regarding obstetric complications. Researchers interviewed women who had experienced $P E / E$, as well as family members of women who experienced PE/E. The data collection activities fall under three broad categories:

\section{Policy level}

1. Desk review of published and unpublished documents from 2000 to 2015;

2. In-depth interviews (IDIs) with policymakers, development partners and Ob/Gyns; and

3. E-Survey of reproductive health program managers in the country.

\section{Health system level}

4. Observations of provider-client interaction during ANC consultations;

5. Client exit interviews at antenatal clinics (after the consultation)

6. Facility inventory; and

7. A self-administered, semi-structured questionnaire for health care providers.

\section{Community level}

8. Focus group discussions with married men and married women; and

9. Case studies of PE/E survivors.

The study took place in six USAID-supported states-Sokoto, Bauchi, Kogi, Cross River, Ebonyi, and Ondo-covering the six geo-political zones in Nigeria. With further support from MacArthur Foundation, a similar exercise took place in Katsina State, making a total of seven research states (see map below), in addition to national level information. This study protocol was reviewed and approved by the Population Council IRB in New York, with additional reviews and approvals by the National Health Research Ethics Committee (NHREC) of the Federal Ministry of Health (FMoH) and the ethics committees of all the participating states. All participants gave their informed consent prior to interview.

Before the study commenced, the Council's research team visited the Federal Ministry of Health (FMoH) and the health authorities of all participating states in order to obtain administrative approval for the study and stakeholders' buy-in. The research team, in collaboration with state ministries of health, obtained the sample of health facilities to be included in each state and surrounding communities. 
All questionnaires were retrieved from the field and immediately transferred to Population Council in Abuja for data entry and analysis. Researchers analyzed data using SPSS software and results were expressed as frequencies and percentages. For the qualitative data, interviews were recorded using hand-written notes, supported by tape recordings. These were then transcribed for content analysis.

FIGURE 1 Map of Nigeria showing the states visited for the study

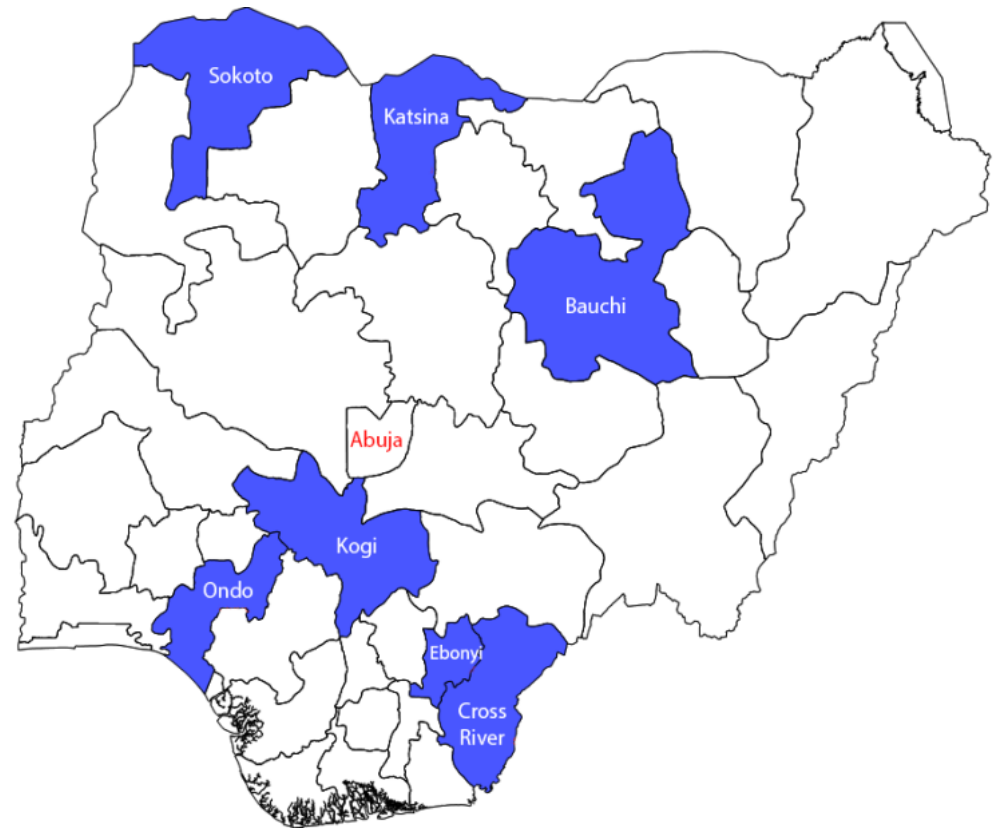

TABLE 1 Summary of quantitative and qualitative data

\begin{tabular}{|c|c|c|c|c|c|c|c|c|c|}
\hline & Bauchi & $\begin{array}{l}\text { Cross } \\
\text { River }\end{array}$ & Ebonyi & Katsina* & Kogi & Ondo & Sokoto & Abuja & Total \\
\hline \multicolumn{10}{|c|}{ Type of Data Collection } \\
\hline \multicolumn{10}{|l|}{ Policy } \\
\hline State IDIs & 10 & 10 & 10 & 10 & 9 & 10 & 10 & & 69 \\
\hline National IDIs & & & & & & & & 3 & 3 \\
\hline \multicolumn{10}{|l|}{ Health System } \\
\hline $\begin{array}{l}\text { Client-provider } \\
\text { observations }\end{array}$ & 28 & 15 & 10 & 9 & 15 & 22 & 37 & & 136 \\
\hline ANC Exit interviews & 28 & 15 & 10 & 9 & 15 & 22 & 37 & & 136 \\
\hline Provider interviews & 55 & 59 & 46 & 55 & 44 & 59 & 61 & & 379 \\
\hline Facility inventory & 14 & 11 & 20 & 21 & 8 & 11 & 11 & & 96 \\
\hline \multicolumn{10}{|l|}{ Community } \\
\hline Women IDIs & 5 & 5 & 5 & 5 & 5 & 5 & 5 & & 35 \\
\hline Community IDIs & 4 & 4 & 4 & 4 & 4 & 4 & 4 & & 28 \\
\hline $\begin{array}{l}\text { Case studies with } \\
\text { families }\end{array}$ & 2 & 2 & 2 & 2 & 2 & 2 & 2 & & 14 \\
\hline
\end{tabular}




\section{STUDY PARTICIPANTS' CHARACTERISTICS/DEMOGRAPHICS}

Table 2 outlines the characteristics of 1) health care providers, and 2) pregnant women observed and interviewed at health facilities.

1. The health care providers $(n=379)$ were interviewed at the facility level who worked in antenatal or maternity units. The majority of providers worked in primary or secondary facilities, while $21 \%$ work in tertiary facilities. Less than $10 \%$ of providers interviewed were medical officers; the rest were mid-level providers. A quarter of providers had been working in the units for one year or less.

2. Pregnant women interviewed were those who attended the surveyed facilities for antenatal care. They were observed during the consultation with the provider (client-provider interaction or $\mathrm{CPI}$ ) and subsequently interviewed before they left the facility (client exit interview). Most of the women surveyed were married, and very few were younger than 19 years. Around one-fifth had no education, but $70 \%$ reported they completed secondary or tertiary education. More than one-third was of low socio-economic status (SES), around half were of middle SES and 16.3\% were of high SES. In comparison, findings from the most recent Nigerian Demographic Health Survey (2013) for the wealth distribution of women of reproductive age surveyed in the country are: Low-37.4\%; Middle-19.2\% and High-43.4\%.

\section{TABLE 2 Characteristics of health providers and pregnant women interviewed}

\begin{tabular}{|c|c|c|c|c|c|}
\hline \multicolumn{3}{|c|}{ Health providers working in maternal health } & \multicolumn{3}{|c|}{ Pregnant women attending ANC } \\
\hline Variable & $\mathrm{n}$ & $\%$ & Variable & $\mathrm{n}$ & $\%$ \\
\hline Sex & & & Marital status & & \\
\hline Male & 56 & 14.8 & Married/Cohabiting & 130 & 96.3 \\
\hline Female & 323 & 85.2 & Formerly married & 5 & 3.7 \\
\hline Age & & & Age & & \\
\hline$<20$ & 5 & 1.3 & $15-19$ & 6 & 4.4 \\
\hline $20-29$ & 83 & 21.9 & $20-24$ & 35 & 25.9 \\
\hline $30-39$ & 111 & 29.3 & $\geq 25$ & 93 & 68.9 \\
\hline $40-49$ & 89 & 23.5 & No response & 1 & 0.7 \\
\hline $50-59$ & 70 & 18.5 & Facility type & & \\
\hline No response & 21 & 5.5 & Tertiary & 28 & 20.7 \\
\hline Facility type & & & Secondary & 69 & 51.1 \\
\hline Tertiary & 80 & 21.1 & Primary & 38 & 28.1 \\
\hline Secondary & 124 & 32.7 & Formal education & & \\
\hline Primary & 175 & 46.2 & None & 29 & 21.5 \\
\hline Type of Provider & & & Primary & 12 & 8.9 \\
\hline Medical practitioner & 35 & 9.2 & Secondary & 41 & 30.4 \\
\hline Nurse/Midwife & 200 & 52.8 & Tertiary & 53 & 39.2 \\
\hline CHEW, $\mathrm{CHO} \&$ Others & 144 & 38.0 & Religion & & \\
\hline Length of time in unit & & & Christians & 60 & 44.4 \\
\hline$<=1 y r$ & 93 & 24.5 & Muslims & 75 & 55.6 \\
\hline$>1-5 r y s$ & 158 & 41.7 & Socio-economic status & & \\
\hline$>5 y r s$ & 89 & 23.5 & Low & 50 & 37.0 \\
\hline No response & 39 & 10.3 & Middle & 63 & 46.7 \\
\hline & & & High & 22 & 16.3 \\
\hline Total & 379 & 100.0 & Total & 135 & 100.0 \\
\hline
\end{tabular}




\section{Results}

\section{SYSTEMATIC REVIEW OF PUBLISHED PAPERS ON PE/E}

The research team developed two sets of key terms related to pre-eclampsia and eclampsia that captured citations for peer-reviewed papers related to detection, management, and prevention of PE/E. The first search was designed to capture results that do not mention PE/E explicitly and the second search included the MeSH (medical subject headings) terms for PE/E and the rare complication known as, HELLP syndrome. This is $\mathbf{H}$ (hemolysis, the breaking down of red blood cells) EL (elevated liver enzymes) LP (low platelet count). The two searches were run in bibliographic databases including: ScienceDirect PubMed, World of Science, Cochrane, POPLINE, and Wiley Online Library. These searches used a combination of terms linking various aspects of the diagnosis, treatment, and prevention of pre-eclampsia, eclampsia and hypertensive disorders of pregnancy. Searches were limited to articles published from 2000 to 2015 (April). After removing duplicate citations and those that were obviously unrelated to this review, the initial database searches identified 520 abstracts, which were included in Phase I review. Two reviewers removed 338 articles that did not fulfill the inclusion requirements for Phase I. During Phase II, 30 articles were removed because they were written about data collected before 2005 and were mainly related to comparing magnesium sulphate and diazepam. A total of 133 articles were included in the systematic review (full report separate).

\section{FIGURE 2 Flow diagram of systematic review methods and results}

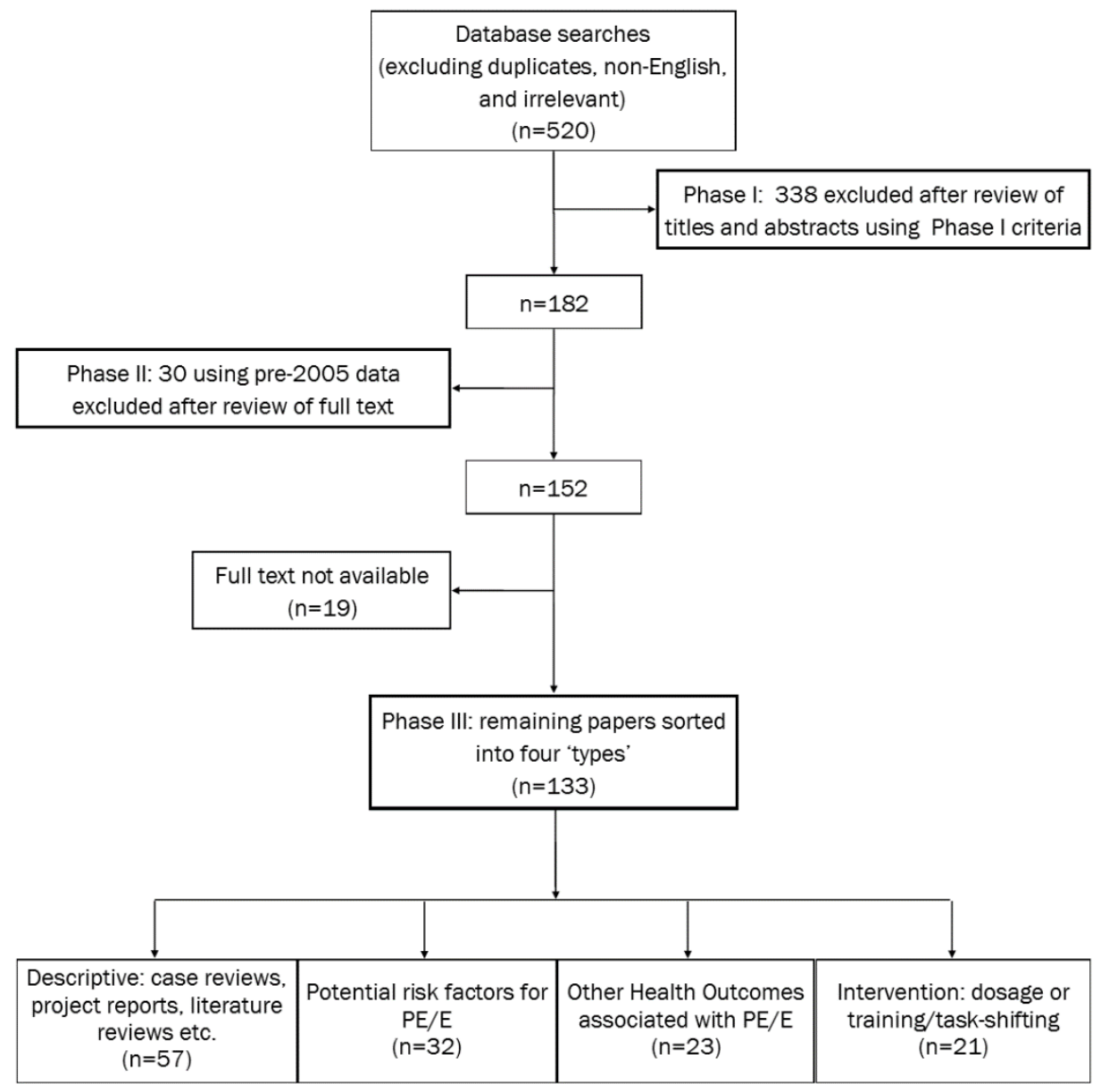




\section{INTERVENTIONS TO REDUCE MATERNAL MORTALITY DUE TO PE/E}

From the articles reviewed, it was clear that the following factors contribute to high maternal morbidity and mortality due to pre-eclampsia and eclampsia: substandard care due to under staffing or un-skilled birth attendants, lack of knowledge on correct use of $\mathrm{MgSO}_{4}$, inadequate antenatal care services, poor attitudes towards clients, and delays in patient care.

Twenty one intervention articles were identified from the researched literature that relate to best practices for detecting, preventing and managing PE/E. Most of the papers focused on studies confirming the dosage regimens and training of clinical providers on the use of $\mathrm{MgSO}_{4}$ as a safe and effective method to treat women with eclampsia in Nigeria and globally. Of these, eight articles were identified as best practice models developed specifically to address the gaps and challenges in the management and treatment of $\mathrm{PE} / \mathrm{E}$ in Nigeria. These interventions were categorized into three main areas for addressing PE/E:

1) Training and re-training of healthcare providers on administering magnesium sulphate

2) Task shifting to increase access to services in primary health care facilities and rural areas

3) Quality of care and protocol development for the management of pre-eclampsia and eclampsia.

In order to improve the quality of care, efforts have been made to develop protocols to train and re-train healthcare providers to screen pregnant mothers during ANC visits and detect signs of pre-eclampsia, as well as administer $\mathrm{MgSO}_{4}$ to patients requiring anticonvulsant therapy. In addition, tools and strategies to ensure standardized services and consistent provider efficacy have been developed based on the local context.

Training and re-training of healthcare providers on administering $\mathrm{MgSO}_{4}$

Although, the role of $\mathrm{MgSO}_{4}$ in reduction of maternal death from eclampsia is well established, its use remains low in many resource poor countries like Nigeria due to lack of availability and inconsistent knowledge and guidelines on its use. There is a need for simplified guidelines that can be adapted contextually to train and re-train doctors, nurses, midwives, and other healthcare providers on the correct dosage and monitoring for toxicity.

Three pre and post intervention study designs focused on developing evidence-based protocols for training and re-training healthcare providers on correctly administering the $\mathrm{MgSO}_{4}$ dosage using the "Pritchard regimen." All three studies showed a significant reduction (approximately $80 \%$ ) in the case fatality rate due to pre-eclampsia and eclampsia (Ezugwu et al. 2014; Okonofua and Ogu 2013; Tukur, Ahonsi, and Ishaku 2013).

Task sharing to increase access and availability of services for PE/E

The utilization of $\mathrm{MgSO}_{4}$ in Nigeria is mostly restricted to secondary and tertiary levels with presumed human and technical capacity to administer and monitor the safety and toxicity of the drugs. A study conducted by Ishaku et al. (2013) showed that task shifting and/or task sharing mechanisms to community health officers (CHOs) and community health extension workers (CHEWs) enabled them to successfully administer $\mathrm{MgSO}_{4}$ in primary healthcare settings. However, the study also indicated that pregnant women who sought services from the $\mathrm{CHEWs}$ and $\mathrm{CHOs}$ did not always follow-up for further treatment. There was a $90 \%$ default rate with referrals - leading researchers to believe that due to the instant relief felt after the administration of the $\mathrm{MgSO}_{4}$ loading dose women and their families may have assumed the treatment was complete and that no further referral was necessary. However, demographic factors indicated that these women were mostly illiterate and the majority were younger than 20 years, which could also play a role in poor adherence to treatment. Adequate counseling and appropriate community mobilization and community-level action are needed to increase adherence for clients to complete their treatment of PE/E. 
In order to address the issues around quality of care and better protocol adherence, Ameh et al. (2012) designed the 'LIVKAN Chart' based on feedback from 118 skilled birth attendants (SBAs). The LIVKAN Chart is a two-page algorithm that lays out key questions and regimens for the treatment and management of $\mathrm{PE} / \mathrm{E}$. This chart is easy to use and has potential to maintain a standardized quality of care across different cadres of health providers and helps to reduce the missed opportunities for treatment of PE/E cases in low resource settings. Of the SBAs who used the chart, 98\% thought it was useful and $73 \%$ of respondents said that lower level healthcare workers could provide better quality of care and good quality documentation for referrals if they used the chart.

A retrospective and comparative study of maternal deaths was conducted between 2004 and 2010 (Igwegbe et al., 2012) to evaluate the impact of the introduction of the Service Compact with all Nigerians (SERVICOM) contract on maternal health at Nnamdi Azikiwe University Teaching Hospital, Nnewi, Nigeria. The main outcome measures were yearly maternal mortality ratio (MMR), relative risk (RR) of maternal mortality, and presentation-intervention interval. The yearly MMR and the RR of maternal mortality were compared with the figures from 2004, which represented the pre-SERVICOM era. The SERVICOM charter was developed by the Federal Government of Nigeria to try to address poor health provider attitudeincluding lateness-to-work, long patient waiting hours, out-of-pocket expenses, and lack of empathy towards clients. SERVICOM "dedicates itself to providing the basic services to which each citizen is entitled in a timely, fair, honest, effective and transparent manner." Under this charter, health providers are mandated to provide quality services designed around the requirements of their customers and all clients must be served by staff sensitive to their needs; commitment to the provision of services within realistic time frames. SERVICOM also provides a waiver for emergency drugs and surgery, and patients were able to pay after adequate resuscitation. Igwegbe et al. found that a positive change in the attitude of health workers and the elimination of fee-for-service in emergency obstetric care could reduce type three delays in public health facilities, and consequently reduce maternal mortality (Igwegbe et al., 2012).

Another case of new protocol development was successfully initiated in Nigeria under the FIGO Saving Mothers and Newborns Initiative (2006-2011), which aimed to provide training on integrated emergency, obstetric and newborn care (EmONC) to strengthen the capacity of national obstetric and midwifery societies to improve EmONC services through protocol development and advocacy activities. Three hundred and sixty eight doctors, nurse-midwives were trained in EmONC in three selected hospitals in Edo, Amambra, and Kaduna. There was a significant reduction (approximately 28\%) in maternal mortality due to eclampsia at the project sites. Furthermore, $\mathrm{MgSO}_{4}$ was supplied to all state hospitals in Kaduna State, four obstetric protocols were introduced, and manufacturers reduced the cost of $\mathrm{MgSO}_{4}$ (Lalonde and Grellier 2012).

Another issue is the quality of antenatal care (ANC) services. While the WHO recommends at least four ANC visits during the pregnancy, less than 39\% of pregnant women seek ANC in Nigeria. In a study conducted by Osungbade et al., 2008, the authors found inadequacies in the content of ANC services at the secondary healthcare facilities area. The screening services and care only had reasonable capacity to provide opportunities for prompt intervention against pre-eclampsia and early detection of some fetal problems. Osungbade et al. concluded that it will be necessary to assess the content of ANC packages as a measure of quality in line with the WHO guidelines to ensure that women are screened for PE/E. Equipping healthcare facilities with capacity to detect high blood pressure and proteinuria is necessary to screen women for preeclampsia and eclampsia (Osungbade 2008). 
Policymakers appear to understand the enormous burden of PE/E and its consequences on maternal and newborn survival, and they know that if $\mathrm{PE}$ is detected during ANC visits, eclampsia and other complications are avoidable. Many policy makers know how the use of $\mathrm{MgSO}_{4}$ shapes maternal and newborn outcomes related to PE/E:

"It is one of the leading causes of maternal death in Ondo state after postpartum hemorrhage. The mortality is high. [It] was very difficult to manage before the advent of magnesium sulphate." Policymaker, Ondo State

Almost all stakeholders, with the exception of those from Ebonyi, agreed there is a need to build the capacity of primary health care $(\mathrm{PHC})$ providers to detect, manage, and refer PE/E patients.

"At the primary level where, if a case like this is detected, the loading dose of $\mathrm{MgSO}_{4}$ should be administered and a quick referral to a tertiary institution should be done. But some of the primary facilities we have around here are not well equipped, and the people working there are not well trained. So at the end of the day, they might not diagnose and refer immediately and sometimes the women present in a bad state. By the time they run around and do one or two things, the patient might deteriorate." Labor ward nurse

Some stakeholders from Ebonyi were against the initial management of PE/E at the PHC level due to perceived incompetence of the $\mathrm{CHEWs}$ to administer $\mathrm{MgSO}_{4}$ safely, despite local and international evidence pointing to the contrary.

"It depends on the capacity of the staff in primary care center because magnesium sulphate is not something anybody can administer... we only allow $\mathrm{MgSO}_{4}$ to be administered by midwives and registered nurse/midwives." Policymaker, Ebonyi

Despite the wide-spread availability of international and local guidelines for managing PE/E, few state level policymakers were aware of these guidelines. However, those with nursing and midwifery backgrounds were more aware of the existence and availability of such documents in their state and even at the facility level. Therefore, it appears as though receipt of evolving national policy documents depends on communication between the federal and state $\mathrm{MOH}$.

$\mathrm{MgSO}_{4}$ is one of the 13 United Nations Life-Saving Commodities for Women and Children, and is also a priority drug for the $\mathrm{FMoH}$, which in 2013 developed a fully-costed implementation plan for $\mathrm{MgSO}_{4}$. Specifically, the Ministry planned to procure and distribute 437,160 vials of $\mathrm{MgSO}_{4}$ at an estimated cost of $\$ 218,580.00$ (Federal Ministry of Health, 2013) for public sector distribution and utilization.

"For the past four or five years, government has even brought in magnesium sulphate and has also given some baseline training to healthcare providers on how to use it." Director of Medical Services and Training, FMoH

To a large extent, national procurement and distribution of $\mathrm{MgSO}_{4}$ has not been accomplished. Although there is a national essential medicines list (EML) and state EMLs (usually based on the national one), it is not clear whether and how $\mathrm{MgSO}_{4}$ is procured at national level. A special budget was created for it among the $13 \mathrm{UN}$ commodities for life saving drugs for mothers and children, but it is not known how active this is as there appears to be no regular $\mathrm{MgSO}_{4}$ procurement and distribution at national or state level. However federally-initiated procurement is not the only option in the country, as private sector procurement covers most of the gaps and some states procure this commodity (and others) through a separate arrangement in an open market. This system is largely ineffective based on the accounts presented by most of the policymakers interviewed. $\mathrm{MgSO}_{4}$ is either not budgeted for, or the allocated funds are not spent appropriately, and secondary and primary health care facilities experience frequent stock outs. 
The affordability of $\mathrm{MgSO}_{4}$ for many clients depends on their income, as out-sourcing from private vendors is now routine. Consequently, stakeholders raised concerns of quality control for drugs obtained outside the hospital. They also expressed fears about the consequences of poor quality drugs for mothers and newborns. These fears are worsened by the fact that there is no known local manufacturer in the country, although pharmaceutical companies are occasionally involved in distributing the drugs at private outlets.

"I will say that magnesium sulphate is readily available, but it's not really very affordable for a poor man; because for a loading dose, you need to administer three ampules of it and its quite expensive for a patient that doesn't really have much." Policymaker, Ebonyi

The World Health Organization recommends using prophylactic low-dose aspirin and calcium supplementation for prevention of pre-eclampsia in high-risk women, but few policymakers and service providers were aware of this, and so the uptake of these preventative practices is low. Policymakers are, however, supportive of this policy and would be willing to review their local strategies and plan for policy change and implementation within their states once they verify the FMoH's support of these preventative measures.

"The state government policy should be that of the National policy, but right now, I am not aware of a policy from the $\mathrm{FMoH}$ that is for the routine use of aspirin. I am not aware it is a policy now. There might be individual doctors based on their professional experience using it, but I am not aware of any policy advocating the use of aspirin as prophylaxis." Policymaker, Ebonyi

There were mixed responses regarding the functionality of the referral system that links community facilities to referral facilities for major obstetric emergencies. Inadequate funding, communication and transportation difficulties, corruption, and influence of traditional birth attendants (TBAs) are among the challenges cited as contributors to the poor referral pathway. Some of the measures suggested to improve the referral pathway include grassroots health education, training of TBAs on referral system, community sensitization, recruiting replacements for retirees, improved road network, improved communication means, and periodic training of healthcare providers.

"Primary healthcare board has midwives in all hospitals. Abiye program has been instituted and is running smoothly. Nurses are trained to refer cases to nearest secondary facility before they become complicated. Delivery and CS are free in all government and mother and child hospitals; hence reducing all delays." Director of Nursing

Policy stakeholders unanimously agreed on the need for community mobilization activities around PE/E. This, they believe, would go a long way in reducing the many problems associated with management of $\mathrm{PE} / \mathrm{E}$. Suggested strategies for this included the use of a mediating team, community sensitization seminars, community engagement workshops, and use of mass media as communications tools. 


\section{DONOR/PARTNER PROGRAMMATIC SUPPORT FOR MATERNAL AND NEWBORN HEALTH IN NIGERIA}

As part of the landscape analysis in Nigeria, we designed an online survey to assess what work related to $\mathrm{MNH}$ is being implemented by international and national partners. The survey aimed to assess the breadth and depth of MNH work, as well as assess the geographic coverage in-country, discover the key funders of $\mathrm{MNH}$ projects, and explore the primary topic areas that programs target. The survey was targeted at representatives of organizations known in Nigeria as well as key international partners; eleven responses were captured.

\section{Current Maternal and Newborn Health Projects}

When asked about the areas of focus for current MNH programs, the most frequently reported topics were quality of care $(n=8)$, pre-eclampsia/eclampsia $(n=7)$, ANC $(n=6)$, maternal mortality death review $(n=6)$, family planning $(n=6)$, severe bleeding/post-partum hemorrhage $(n=6)$, task-shifting $(n=6)$, and Emergency Obstetric and Newborn Care (EmONC) $(n=5)$. These programs are being implemented in 23 of Nigeria's 36 states and in Abuja, the Federal Capital Territory. Five respondents reported implementing MNH programs in Kano State. The next most commonly reported states with four responses each were Jigawa, Kaduna, Lagos, Sokoto and Zamfara.

MNH projects are being implemented across all levels of the health system. Most of the respondents reported working at multiple levels: Six reported working in tertiary level hospitals, seven in teaching hospitals, ten in secondary level facilities, ten in primary care centers, five work in community clinics, and seven said that they work in communities. The organizations implementing these projects reported that their work has the most influence related to advocacy $(n=8)$, policy $(n=7)$, and service delivery $(n=4)$.

\section{Current Funders of Maternal and Newborn Health Projects}

The most often reported funding organizations include: USAID, The John D. and Catherine T. MacArthur Foundation, the Bill and Melinda Gates Foundation, and Merck for Mothers Giving Program. The Ford Foundation, T.Y. Foundation, WHO, International Development Research Centre (IDRC), and Canada were also cited as current donors for MNH programs in Nigeria. 


\section{National Stakeholders Views on PE/E}

In addition to the above we also asked a range of stakeholders, who attended the dissemination meeting in Abuja in August 2015, their opinion on issues related to programing for prevention and treatment of PE/E (see Box 1). The stakeholders were from international and national NGOs, state level health managers and donors.

\begin{tabular}{|c|c|}
\hline 30X 1: Stakeh & lers' views on current issues around PE/E \\
\hline Question & Participant Response \\
\hline What are the & No adequate health policy in place to prevent and treat PE. \\
\hline $\begin{array}{l}\text { bottlenecks at } \\
\text { system or }\end{array}$ & $\begin{array}{l}\text { Health System failure: } 1 \text { ) the } \mathrm{FMoH} \text { is lagging and the } 3^{\circ} \text { and } 2^{\circ} \text { and } 1^{\circ} \text { facilities do } \\
\text { not have essential medicines equitably provided, especially } 2 \text { ) weak human }\end{array}$ \\
\hline facility level? & resources e.g. Skilled birth attendants, and 3) literacy is a major bottleneck. \\
\hline & Delay in obstetric care and decision making to seek care at a facility. \\
\hline & Delays in referral and treatment, and inadequate drugs. \\
\hline & Limited supportive supervision and low commitment from the policy makers. \\
\hline & Poor attitudes of health workers at the facilities. \\
\hline & Challenges of sustainability, which requires strong advocacy to policy makers. \\
\hline & Policy makers to consider maternal health issues as a top priority. \\
\hline What are the & Proper coordination of all stakeholders. \\
\hline potential areas & Improved information sharing and communication. Basket funding. \\
\hline of synergy? & Liaise with the state/local government in terms of provision of basic amenities. \\
\hline & Make $\mathrm{MgSO}_{4}$ available at all levels. \\
\hline & Ensure proper management of health care. \\
\hline $\begin{array}{l}\text { How can } \\
\text { communities be }\end{array}$ & $\begin{array}{l}\text { Educate community about the benefits and importance of ANC and negative effect of } \\
\text { not attending facility before and after birth through advocacy. }\end{array}$ \\
\hline more engaged? & $\begin{array}{l}\text { Involve community leaders and gatekeepers at the table from the onset and } \\
\text { throughout the program concept/development/implementation. }\end{array}$ \\
\hline & Communicate in language(s)/channels that they understand. \\
\hline & $\begin{array}{l}\text { Engage with: women's groups, traditional leaders, men, and faith-based home/birth } \\
\text { attendants (including TBAs). }\end{array}$ \\
\hline What are & Early detection of pre-eclampsia and prompt delivery of eclamptic women. \\
\hline promising & $\mathrm{MgSO}_{4}$ readily available at the central medical store. \\
\hline practices? & Increase in ANC attendance. \\
\hline & Early diagnosis and management to reduce morbidity and mortality. \\
\hline & TBA referrals for ANC after receiving training. \\
\hline & $\begin{array}{l}\mathrm{CHWs} \text { trained to identify } \mathrm{PE} / \mathrm{E} \text {, and to give appropriate stabilizing care before } \\
\text { referring women. }\end{array}$ \\
\hline Other & Lack of political will and of sustainability of existing successful programs. \\
\hline challer & Attitudes of policy makers and health workers. \\
\hline gaps? & Partners working on RMNCH need to pool resources together. \\
\hline & $\begin{array}{l}\text { USAID needs to coordinate the process because there is so much verticalization of } \\
\text { the same activities. }\end{array}$ \\
\hline & No involvement of traditional religious bodies. \\
\hline & $\begin{array}{l}\text { Transportation-bad road to facilities. Access: too hard to reach remote areas. Poor } \\
\text { network in the community area. }\end{array}$ \\
\hline & Traditional beliefs and cultural/religious practices. \\
\hline & Knowledge and attitude of $\mathrm{cl}$ \\
\hline
\end{tabular}




\section{HEALTH SYSTEM LEVEL}

A range of health providers working in ANC, maternity and labor/delivery wards were interviewed, we observed provider-client interactions during ANC consultations, conducted a facility inventory assessment, and collected a self-administered, semi-structured questionnaire for front-line health care providers. This study investigated providers' knowledge, practice, skills, and experiences in preventing detecting, and managing PE/E. For the purpose of this study, the definitions used throughout this study are presented in Box 2.

\section{BOX 2: Definitions}

Pre-eclampsia is the development of hypertension and significant proteinuria for the first time after 20 weeks of gestation.

- Hypertension is defined as blood pressure (BP) measurement of $\geq 140 \mathrm{mmHg}$ systolic and/or BP of $\geq 90 \mathrm{mmHg}$ diastolic measured on two consecutive occasions six hours apart.

- Significant proteinuria is defined as protein of $0.3 g$ in 24 hours collection of urine, or a urine protein estimation that is $\geq 2(++)$ using dipsticks.

Severe pre-eclampsia is associated with symptoms and clinical manifestations such as severe headache, changes in vision (including temporary loss of vision/blurred vision, light sensitivity, seeing spots), upper abdominal pain (usually under ribs on the right side, nausea/vomiting, dizziness, and decreased urine output.

Eclampsia is defined as the occurrence of chronic convulsions in a pregnant woman with the absence of any neurological cause.

Chronic hypertension in pregnancy is defined as a pregnant woman with a BP recording of $160 / 100 \mathrm{mmHg}$ with no proteinuria.

\section{Knowledge and practice of healthcare providers for the prevention of PE}

Researchers assessed health care providers' knowledge of proven risk factors for PE, including chronic hypertension, obesity, pre-existing diabetes or diabetes in pregnancy, advanced maternal age ( $\geq 35$ years), sickle cell diseases, previous history of PE/E, and connective tissue diseases.

The following definitions were used to measure provider awareness for the prevention of eclampsia:

\begin{tabular}{|ll|}
\hline Assessing the risk of PE: & $\begin{array}{l}\text { History of hypertension/high BP, history of diabetes, asked about } \\
\text { date of last delivery, client's weight, checked edema (face, hands, } \\
\text { legs and ankles), pregnancy order, and client's age. }\end{array}$ \\
$\begin{array}{l}\text { Detecting PE: } \\
\begin{array}{l}\text { Advising on symptoms of } \\
\text { impending eclampsia: }\end{array}\end{array}$ & $\begin{array}{l}\text { Severe headache, blurred vision and pre-eclampsia with generalized } \\
\text { body swelling. }\end{array}$ \\
\hline
\end{tabular}


Only 15 percent of the providers interviewed $(n=379)$ across the seven states reported that they look for risk factors related to PE during ANC consultations (Figure 3 ).

\section{FIGURE 3 Results from ANC provider-client observations $(n=379)$}

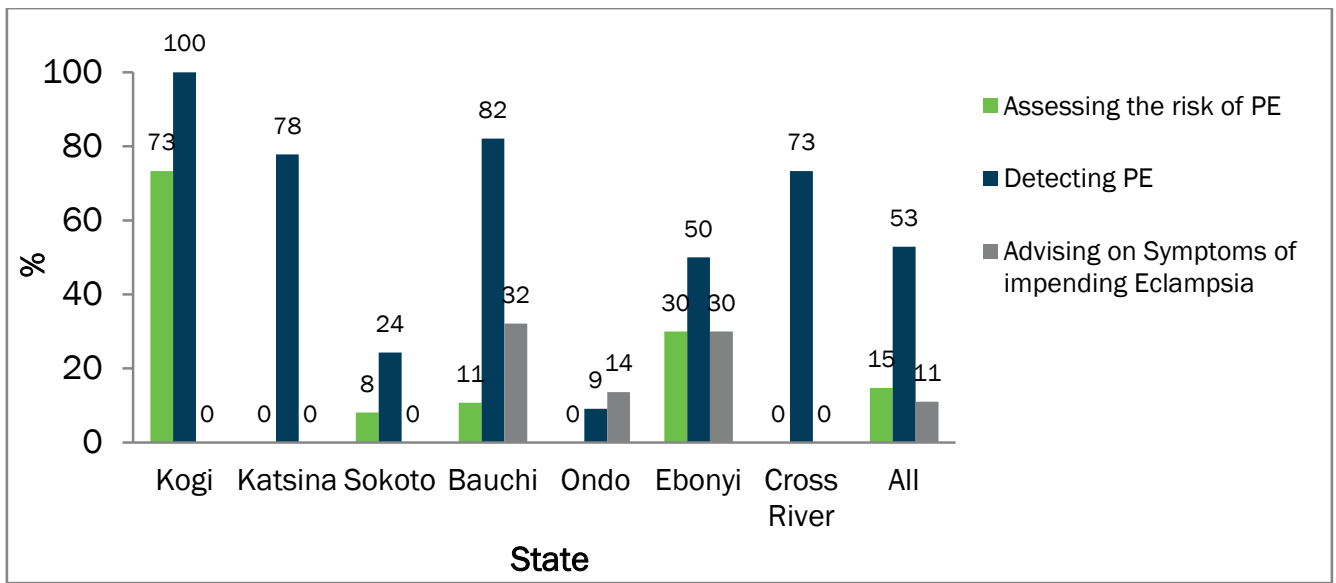

The study further investigated whether providers were aware of, or ever used, any prophylactic drugs, to prevent PE among pregnant women at risk. Overall, only 19 percent $(n-79)$ of providers were aware of prophylactic drugs to prevent PE. Out of these 79 providers, 14 percent mentioned aspirin $5 \%$ mentioned calcium supplements, 58 percent mentioned other drugs (incorrectly) and 23 percent did not know which drugs. This varied widely between states. For example, of the 6 Ebonyi providers who knew that prophylactic drugs could be used to prevent PE, two mentioned aspirin, one mentioned calcium and three mentioned other drugs. In Sokoto none of the providers were aware of the prophylactic use of aspirin and calcium. Moreover, some of the providers appeared to be confused regarding indications for these drugs during pregnancy.

The providers who did not know of aspirin or calcium prophylaxis for PE prevention (58\%) but mentioned other drugs listed aldomet, hydralazine, or nifedipine (which are used to lower blood pressure) and phenobarbitone, and diazepam (which were previously used for managing convulsions). This shows that many providers do not understand the difference between prophylaxis and treatment.

The medical practitioners-obstetricians and gynecologists (15\% of providers interviewed) -were more likely to use aspirin prophylaxis for high-risk women and use anti-hypertensives in pregnant women with high blood pressure. Those with more years of experience of working in a maternity unit gave aspirin prophylaxis, but there was no difference in experience for those prescribing anti-hypertensives. Previous exposure to training in maternal and child health $(\mathrm{MCH})$ had a positive effect on the provision of aspirin prophylaxis and anti-hypertensives. Table 3 shows the use of aspirin prophylaxis and anti-hypertensives by provider type, facility level experience and training. 


\section{TABLE 3 Use of Aspirin and Anti-hypertensive drugs for women who are at risk of developing PE/E}

\begin{tabular}{|c|c|c|c|c|c|c|}
\hline & \multicolumn{3}{|c|}{$\begin{array}{l}\text { Use aspirin among women who are at risk } \\
\text { of developing PE }\end{array}$} & \multicolumn{3}{|c|}{$\begin{array}{l}\text { Use anti-hypertensive drugs for pregnant } \\
\text { women who have high BP }\end{array}$} \\
\hline & $\begin{array}{l}\% \text { Correct } \\
\text { response }\end{array}$ & p-value & $\mathrm{n}=\mathbf{3 7 9}$ & $\begin{array}{l}\% \text { Correct } \\
\text { response }\end{array}$ & p-value & $N=379$ \\
\hline \multicolumn{7}{|l|}{ Type of provider } \\
\hline Medical practitioners & 22.9 & \multirow{3}{*}{0.000} & 35 & 65.7 & \multirow{3}{*}{0.000} & 35 \\
\hline Nurses/Midwives & 11.5 & & 200 & 48.5 & & 200 \\
\hline CHEWs, CHOs \& Others & 2.8 & & 144 & 31.9 & & 144 \\
\hline \multicolumn{7}{|l|}{ Type of facility } \\
\hline Tertiary & 8.8 & \multirow{3}{*}{0.003} & 80 & 51.3 & \multirow{3}{*}{0.076} & 80 \\
\hline Secondary & 16.1 & & 124 & 47.6 & & 124 \\
\hline Primary & 4.6 & & 175 & 37.7 & & 175 \\
\hline \multicolumn{7}{|c|}{ Years working in present unit/ward } \\
\hline$\leq 1$ years & 8.6 & \multirow{4}{*}{0.895} & 93 & 49.5 & \multirow{4}{*}{0.334} & 93 \\
\hline$>1-5$ years & 8.9 & & 158 & 41.8 & & 158 \\
\hline$>5$ years & 11.2 & & 89 & 46.1 & & 89 \\
\hline No response & 7.7 & & 39 & 33.3 & & 39 \\
\hline \multicolumn{7}{|c|}{ Received any training on maternal health, FP or child health care } \\
\hline Yes & 12.9 & \multirow{2}{*}{0.012} & 194 & 49.5 & \multirow{2}{*}{0.022} & 194 \\
\hline No & 5.4 & & 185 & 37.8 & & 185 \\
\hline
\end{tabular}

\section{The capacities of healthcare providers to detect hypertensive disorders in pregnancy}

Healthcare providers were asked a number of questions relating to hypertensive disorders in pregnancy. Overall, less than half $(48.5 \%)$ of all providers could identify chronic hypertension in pregnancy when responding to a hypothetical case study about a 12-week pregnant woman presenting for ANC with a blood pressure recording of 160/100 mmHg with no proteinuria. The proportions of providers who could correctly identify chronic hypertension in pregnancy for each state are Bauchi $=34.5 \%$, Cross River $=50.8 \%$, Ebonyi $=52.2 \%$, Katsina $=40.0 \%$, Kogi $=43.2 \%$, Ondo $=61.0 \%$, and Sokoto $=55.7 \%$.

The majority of providers were able to identify the signs and symptoms of pre-eclampsia (64\%) and eclampsia (81\%), with some range between states (Figure 4). Few providers could identify severe PE using symptoms other than severe hypertension and significant proteinuria. The diagnosis of severe PE is an important landmark in decision-making in PE management and eclampsia prevention. 

eclampsia?

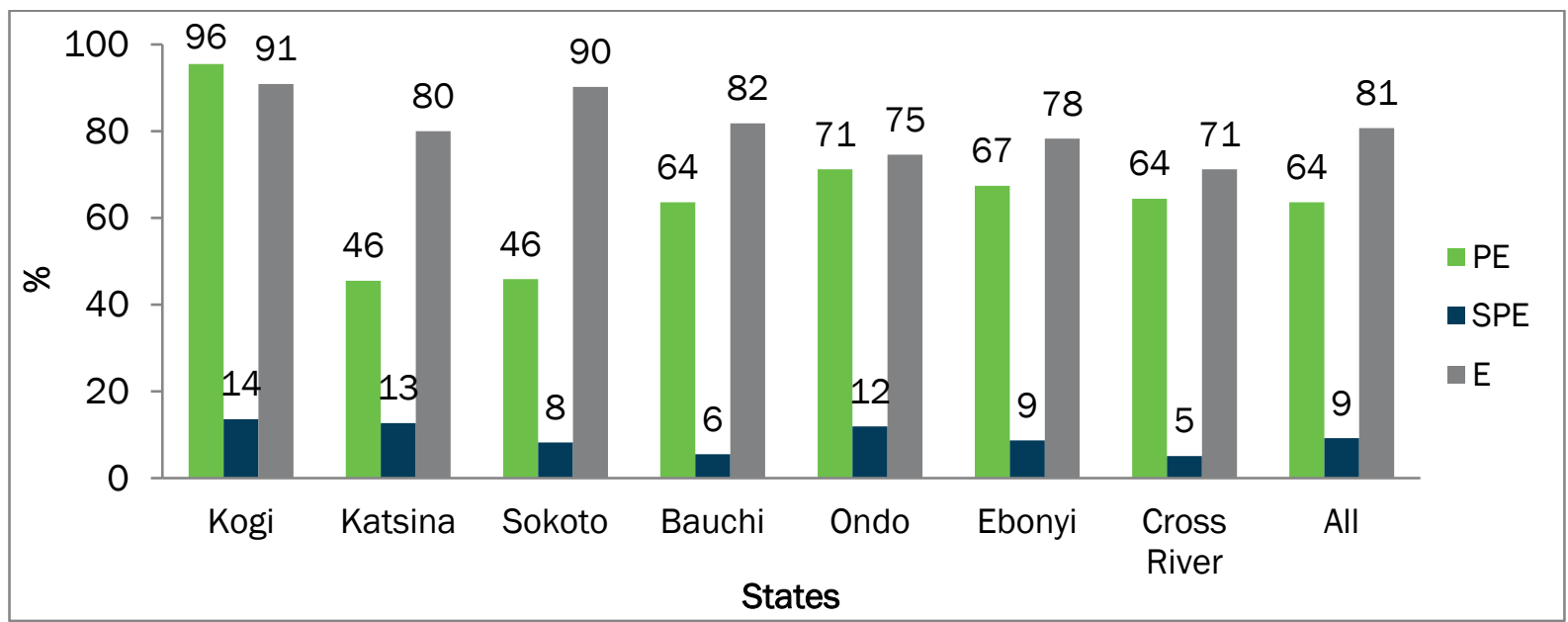

The knowledge and ability of providers to detect and classify hypertensive disorders in pregnancy were further analyzed against independent variables: the cadres of health providers, types of facilities, length of time they worked in their respective facilities, and whether they received $\mathrm{MCH}$ training (Table 4). Health providers with more training are better able to correctly classify severe PE, chronic hypertension in pregnancy, and eclampsia. However, there is no direct correlation between correct clinical classification with facility type, years of service, or previous exposure to $\mathrm{MCH}$ training.

\section{TABLE 4 Provider knowledge to diagnose chronic hypertension, SPE and E}

\begin{tabular}{|c|c|c|c|c|c|c|c|c|c|}
\hline & \multicolumn{3}{|c|}{$\begin{array}{l}\text { A pregnant woman presents } \\
\text { at } 12 \text { weeks with BP } \\
160 / 100 \mathrm{mmHg} \text { with no } \\
\text { proteinuria (Chronic } \\
\text { hypertension in pregnancy) }\end{array}$} & \multicolumn{3}{|c|}{$\begin{array}{l}\text { A pregnant woman presents at } \\
\text { ANC at } 30 \text { weeks with BP of } \\
180 / 115 \mathrm{mmHg} \text { and proteinuria } \\
\text { of } 2++ \text { (Severe pre-eclampsia) }\end{array}$} & \multicolumn{3}{|c|}{$\begin{array}{l}\text { A pregnant woman developed } \\
\text { hypertension and significant } \\
\text { proteinuria at } 30 \text { weeks. } \\
\text { Brought back a week later with } \\
\text { convulsions (Eclampsia) }\end{array}$} \\
\hline & $\begin{array}{l}\% \text { Correct } \\
\text { diagnosis }\end{array}$ & $\begin{array}{c}\text { p- } \\
\text { value }\end{array}$ & $N=379$ & $\begin{array}{l}\% \text { Correct } \\
\text { diagnosis }\end{array}$ & p-value & $\mathrm{N}=379$ & $\begin{array}{l}\% \text { Correct } \\
\text { diagnosis }\end{array}$ & $\begin{array}{c}\mathrm{p}- \\
\text { value }\end{array}$ & $\begin{array}{c}\mathrm{N}=37 \\
9\end{array}$ \\
\hline \multicolumn{10}{|l|}{ Type of provider } \\
\hline Medical practitioner & 82.9 & \multirow{3}{*}{0.000} & 35 & 85.7 & \multirow{3}{*}{0.000} & 35 & 94.3 & \multirow{3}{*}{0.000} & 35 \\
\hline Nurse/Midwife & 52.5 & & 200 & 79.5 & & 200 & 83.0 & & 200 \\
\hline CHEW/CHO/ Others & 34.7 & & 144 & 61.8 & & 144 & 61.1 & & 144 \\
\hline \multicolumn{10}{|l|}{ Type of facility } \\
\hline Tertiary & 56.3 & \multirow{3}{*}{0.000} & 80 & 76.3 & \multirow{3}{*}{0.001} & 80 & 83.8 & \multirow{3}{*}{0.000} & 80 \\
\hline Secondary & 59.7 & & 124 & 83.9 & & 124 & 86.3 & & 124 \\
\hline Primary & 37.1 & & 175 & 64.6 & & 175 & 64.6 & & 175 \\
\hline \multicolumn{10}{|c|}{ Years working in present unit/ward } \\
\hline$\leq 1$ years & 60.2 & \multirow{4}{*}{0.071} & 93 & 71.0 & \multirow{4}{*}{0.820} & 93 & 80.6 & \multirow{4}{*}{0.043} & 93 \\
\hline$>1-5$ years & 43.7 & & 158 & 74.7 & & 158 & 72.8 & & 158 \\
\hline$>5$ years & 44.9 & & 89 & 75.3 & & 89 & 82.0 & & 89 \\
\hline No response & 48.7 & & 39 & 69.2 & & 39 & 61.5 & & 39 \\
\hline \multicolumn{10}{|c|}{ Received any training on maternal health, FP or child health care } \\
\hline Yes & 49.0 & \multirow{2}{*}{0.867} & 194 & 74.2 & \multirow{2}{*}{0.693} & 194 & 78.9 & \multirow{2}{*}{0.144} & 194 \\
\hline No & 48.1 & & 185 & 72.4 & & 185 & 72.4 & & 185 \\
\hline
\end{tabular}




\section{The capacity of health facilities and service providers to manage pre-eclampsia and associated morbidities}

Health facilities must be equipped with relevant life-saving commodities, equipment and drugs. To detect $\mathrm{PE} / \mathrm{E}$ during ANC visits, facilities must have sphygmomanometers and stethoscopes to measure blood pressure and urine dipsticks to enable rapid assessment of urine sample for significant proteinuria. During this landscape analysis, 96 facilities were assessed in the seven states. Table 5 presents the proportion of facilities that were equipped with specific ANC commodities and equipment to detect PE. Availability of dipsticks to test for proteinuria and urine collection containers is low overall but more so at secondary and tertiary levels. Primary level facilities are less likely to have functioning stethoscopes and sphygmomanometers.

\section{TABLE 5 Proportion of facilities that have the key ANC equipment to detect pre- eclampsia}

\begin{tabular}{|c|c|c|c|c|c|}
\hline State & $\begin{array}{c}\text { Are there } \\
\text { functioning } \\
\text { stethoscopes? }\end{array}$ & $\begin{array}{l}\text { Are there functioning } \\
\text { Sphygmomanometers? }\end{array}$ & $\begin{array}{c}\text { Are there dipsticks } \\
\text { for testing protein in } \\
\text { urine? }\end{array}$ & $\begin{array}{l}\text { Do you have clean } \\
\text { containers for urine } \\
\text { collection? }\end{array}$ & $\begin{array}{l}\text { Total Number } \\
\text { of facilities } \\
\text { visited }\end{array}$ \\
\hline & Yes (\%) & Yes (\%) & Yes (\%) & Yes (\%) & \\
\hline Cross River & 72 & 82 & 46 & 46 & 11 \\
\hline Ebonyi & 65 & 50 & 55 & 50 & 20 \\
\hline Ondo & 64 & 73 & 27 & 46 & 11 \\
\hline Kogi & 87 & 88 & 25 & 50 & 8 \\
\hline Sokoto & 91 & 91 & 45 & 55 & 11 \\
\hline Katsina & 86 & 79 & 50 & 64 & 14 \\
\hline Bauchi & 81 & 76 & 57 & 81 & 21 \\
\hline Total & 77 & 74 & 47 & 58 & 96 \\
\hline \multicolumn{6}{|c|}{ Availability by level of facility } \\
\hline & Yes (\%) & Yes (\%) & Yes (\%) & Yes (\%) & \\
\hline Tertiary & 90 & 100 & 40 & 60 & 10 \\
\hline Secondary & 82 & 85 & 37 & 48 & 27 \\
\hline Primary & 73 & 64 & 53 & 63 & 59 \\
\hline Total & 77 & 74 & 47 & 58 & 96 \\
\hline
\end{tabular}

Figure 5 shows that less than one-third (31\%) of facilities had all the necessary equipment and supplies, and a little more than one-third (34\%) had $\mathrm{MgSO}_{4}$ available in the labor and maternity units when the researchers visited. Less than one-fifth of facilities had the correct guidelines in place for managing $P E / E$, including for the administration of $\mathrm{MgSO}_{4}$. When researchers visited the facilities in Sokoto, no facilities had protocols or guidelines in place, only 9 percent stocked $\mathrm{MgSO}_{4}$ and 18 percent had the essential tools and equipment. 
FIGURE 5 Availability of guidelines for management of PE/E, ANC equipment to detect pre-eclampsia and manage $\mathrm{PE} / \mathrm{E}$ using $\mathrm{MgSO}_{4}$

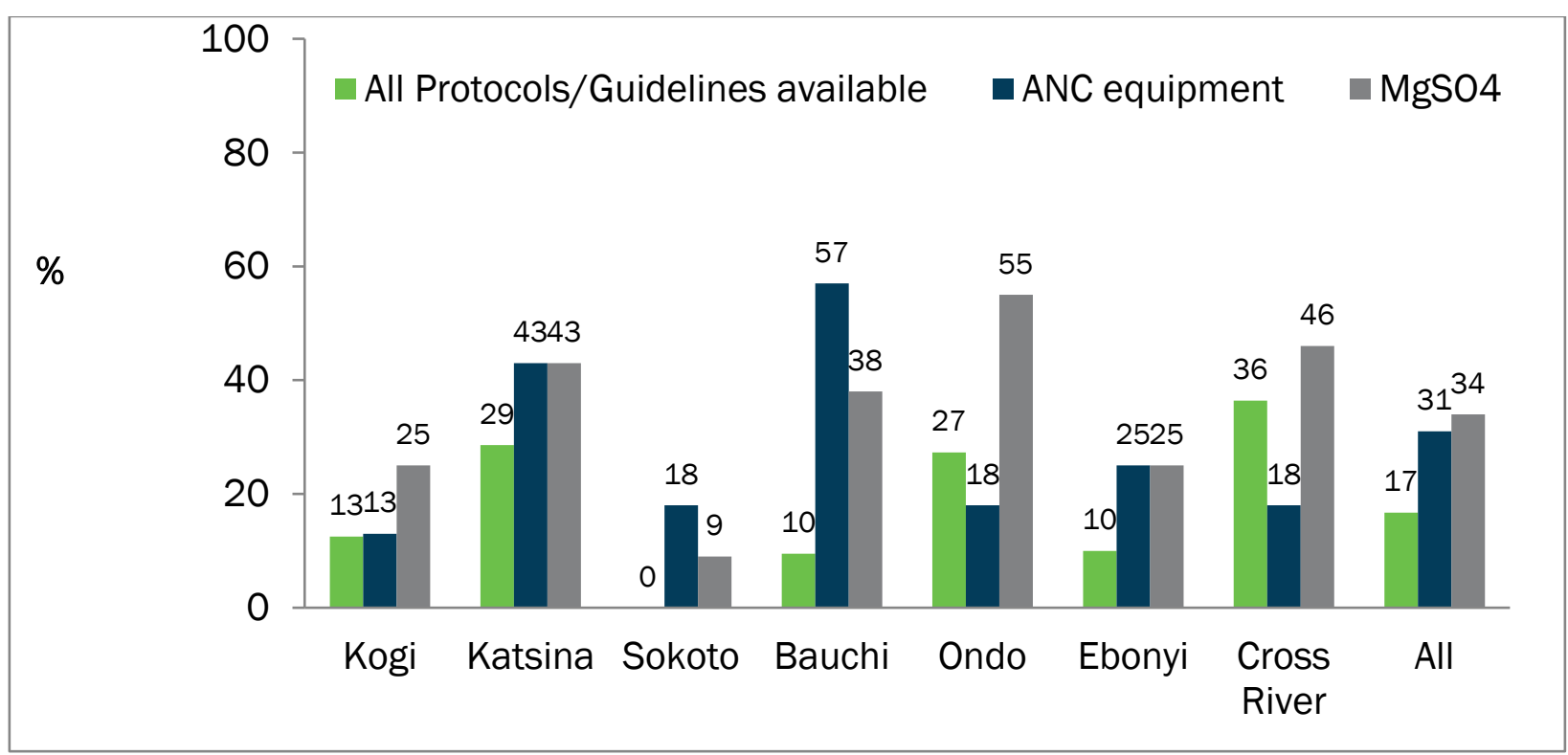

Table 6 outlines the proportion of facilities that have the key drugs, equipment and supplies to treat PE/E and monitor for $\mathrm{MgSO}_{4}$ toxicity. Majority of facilities to do not have patella hammers or urine catheters and bags to measure urine output. More facilities are using $\mathrm{MgO}_{4}$ than have the correct antidote (calcium gluconate).

TABLE 6 Proportion of facilities that have the key drugs and equipment to manage $\mathrm{SPE} / \mathrm{E}$ and observe for $\mathrm{MgSO}_{4}$ toxicity

\begin{tabular}{|lccccccc|}
\hline & $\begin{array}{c}\text { Anti- } \\
\text { hypertensives }\end{array}$ & $\mathrm{MgSO}_{4}$ & $\begin{array}{c}\text { Patella } \\
\text { Hammer }\end{array}$ & $\begin{array}{c}\text { Urine } \\
\text { Catheter }\end{array}$ & Urine bag & $\begin{array}{c}\text { Calcium } \\
\text { Gluconate }\end{array}$ & $\begin{array}{c}\text { Total } \\
\text { Number } \\
\text { of } \\
\text { facilities }\end{array}$ \\
\hline Cross River & Yes $(\%)$ & Yes $(\%)$ & Yes $(\%)$ & Yes $(\%)$ & Yes $(\%)$ & Yes $(\%)$ & \\
\hline Ebonyi & 0 & 46 & 0 & 46 & 36 & 20 & 11 \\
\hline Ondo & 5 & 25 & 5 & 45 & 15 & 0 & 20 \\
\hline Kogi & 55 & 55 & 18 & 64 & 64 & 43 & 11 \\
\hline Sokoto & 38 & 25 & 13 & 71 & 57 & 0 & 8 \\
\hline Katsina & 9 & 9 & 9 & 64 & 64 & 13 & 11 \\
\hline Bauchi & 0 & 43 & 36 & 57 & 57 & 30 & 14 \\
\hline Total & 10 & 38 & 10 & 57 & 43 & 6 & 21 \\
\hline
\end{tabular}


Figure 6 demonstrates the other critical commodities and equipment required in the maternity/labor ward to manage complications.

\section{FIGURE 6 Proportion of all facilities with emergency equipment, supplies and drugs for EmONC}

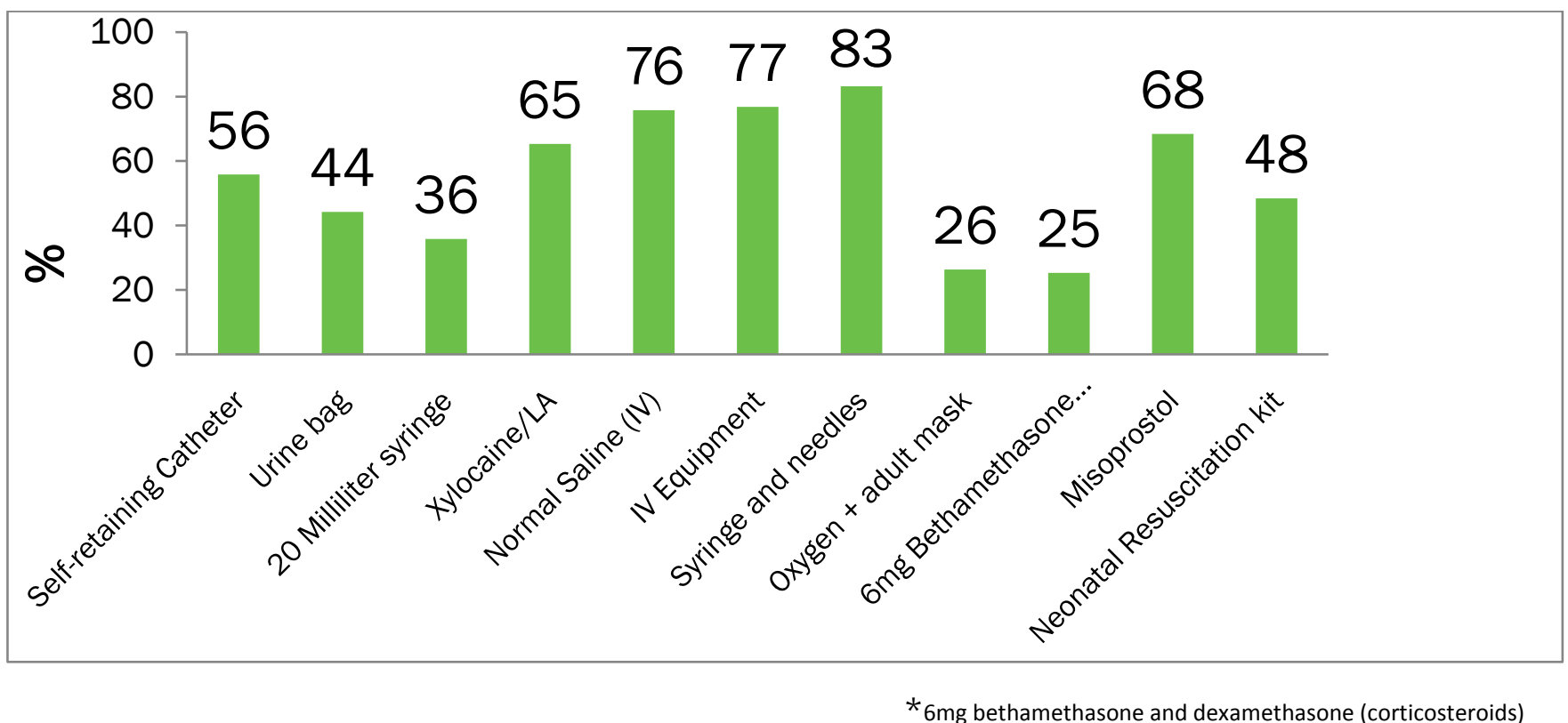

Providers must possess the knowledge and skills to manage PE/E appropriately. Specifically, in hypertensive disorders during pregnancy, providers must know how to manage hypertension using the recommended anti-hypertensives at the right time. They must also know how to administer anticonvulsants, such as $\mathrm{MgSO}_{4}$ and calcium gluconate, if required.

In this study, researchers asked healthcare providers about commonly used anti-hypertensives for managing mild to moderate hypertension in pregnancy. Most guidelines first recommend labetalol, and nifedipine or aldomet as suitable alternatives (UK National Institute for Health and Care Excellence, 2010). As labetalol is not widely available in Nigeria, nifedipine and aldomet are often the drugs of choice. Only 41percent of health providers mentioned aldomet or nifedipine as drugs of choice for managing mild to moderate hypertension in pregnancy. In all states, with the exception of Ondo, less than half of providers gave the correct responses (Bauchi $=42 \%$, Cross River $=36 \%$, Ebonyi $=28 \%$, Katsina $=49 \%$, Kogi $=46 \%$, Ondo $=53 \%$, and Sokoto $=33 \%$ ).

Standard practice recommends initiating anti-hypertensives in pregnant women with mild to moderate hypertension at blood pressure level of $\geq 150 / 100 \mathrm{mmHg}$ (UK - National Institute for Health and Care Excellence, 2010). When blood pressure is $\geq 160 / 110 \mathrm{mmHg}$, the use of vasodilators to rapidly lower the blood pressure to a safer level (diastolic $<110 \mathrm{mmHg}$ ) is also recommended. Only 2 percent of providers knew when to introduce anti-hypertensive drugs in women with mild to moderate hypertension. Table 6 shows poor provider knowledge for introducing anti-hypertensives in pregnant women with hypertensive disorders, such as PE. There is no correlation between the type of facility and which providers know when to start anti-hypertensives. Knowledge gaps persisted across providers at primary, secondary, or tertiary facilities. 
TABLE 7 Knowledge of BP measurement when anti-hypertensives are introduced for moderate and severe hypertension

\begin{tabular}{|c|c|c|c|c|c|c|}
\hline & \multicolumn{3}{|c|}{ Mild to moderate hypertension } & \multicolumn{3}{|c|}{ Severe hypertension } \\
\hline & $\%$ Correct response & $\mathrm{p}$-value & $\begin{array}{c}n= \\
379\end{array}$ & $\%$ Correct response & p-value & $\begin{array}{c}n= \\
379\end{array}$ \\
\hline \multicolumn{7}{|l|}{ Type of provider } \\
\hline Medical practitioner & 2.9 & \multirow{3}{*}{0.323} & 35 & 5.7 & \multirow{3}{*}{0.071} & 35 \\
\hline Nurse/Midwife & 3.0 & & 200 & 5.0 & & 200 \\
\hline $\begin{array}{l}\text { CHEW. CHO \& } \\
\text { Others }\end{array}$ & 0.7 & & 144 & 0.7 & & 144 \\
\hline \multicolumn{7}{|l|}{ Type of facility } \\
\hline Tertiary & 2.5 & \multirow{3}{*}{0.118} & 80 & 2.5 & \multirow{3}{*}{0.015} & 80 \\
\hline Secondary & 4.0 & & 124 & 7.3 & & 124 \\
\hline Primary & 0.6 & & 175 & 1.1 & & 175 \\
\hline \multicolumn{7}{|c|}{ Years working in present unit/ward } \\
\hline$\leq 1$ years & 1.1 & \multirow{4}{*}{0.617} & 93 & 1.1 & \multirow{4}{*}{0.359} & 93 \\
\hline$>1-5$ years & 3.2 & & 158 & 3.2 & & 158 \\
\hline$>5$ years & 1.1 & & 89 & 5.6 & & 89 \\
\hline No response & 2.6 & & 39 & 5.1 & & 39 \\
\hline \multicolumn{7}{|c|}{ Received any training on maternal health, FP or child health care } \\
\hline Yes & 0.5 & \multirow{2}{*}{$0.033^{*}$} & 194 & 3.6 & \multirow{2}{*}{0.845} & 194 \\
\hline No & 3.8 & & 185 & 3.2 & & 185 \\
\hline
\end{tabular}

A crucial component of managing $\mathrm{PE} / \mathrm{E}$ is the use of anticonvulsants. Evidence recommends $\mathrm{MgSO}_{4}$ as the 'gold standard' for preventing and treating convulsions in severe $\mathrm{PE} / \mathrm{E}$. Administering $\mathrm{MgSO}_{4}$ intramuscularly (Pritchard regimen ${ }^{1}$ ) is preferred and is the most utilized regimen. In this regimen, a dose of 14 grams of $\mathrm{MgSO}_{4}$ is administered as the loading dose, followed by five grams intramuscularly into alternate buttocks every four hours for maintenance. Only 12 percent and 10 percent of health care providers knew the correct loading and maintenance doses of $\mathrm{MgSO}_{4}$, respectively. Figure 7 shows the proportion of health providers, who knew the correct amount used in a loading dose.

\section{FIGURE 7 Correct knowledge of loading dose of $\mathrm{MgSO}_{4}$ for $\mathrm{PE} / \mathrm{E}$ (Pritchard regimen)}

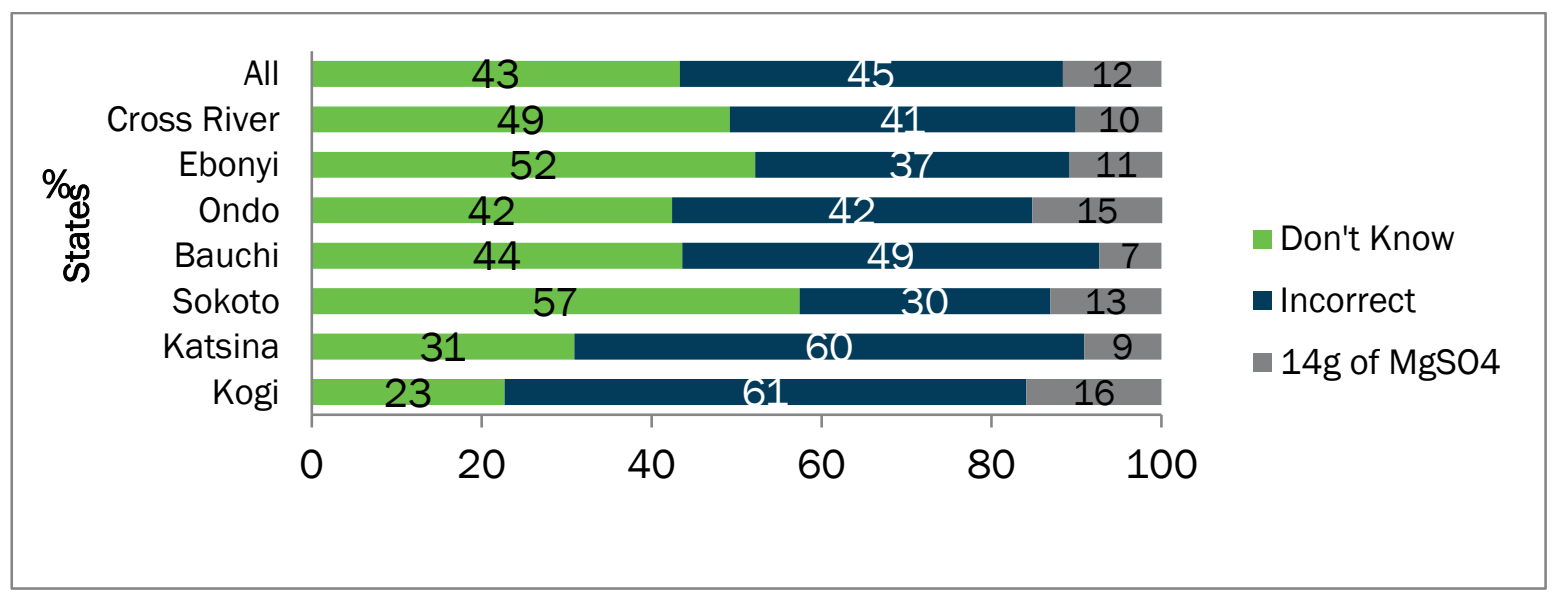

\footnotetext{
1 The alternative regimen is the Zuspan regimen where $\mathrm{MgSO}_{4}$ is administered intravenously at a given rate using an infusion pump. Because infusion pumps are generally not available in most developing countries, Nigeria adopted the Pritchard regimen for all of levels of health care services.
} 
Table 8 indicates the knowledge of loading and maintenance doses of $\mathrm{MgSO}_{4}$ among the health providers in respect to their medical qualifications, years of experience, type of facility, and whether they received prior $\mathrm{MCH}$ training. Although overall knowledge is low significantly more medical practitioners knew the loading dose (compared to other lower level cadres), but more nurse/midwives knew the maintenance dose. Significant differences were also noted at level of facility where significantly more providers at secondary level facilities knew the loading dose, yet tertiary level providers knew the maintenance dose.

\section{TABLE 8 Knowledge of total loading and maintenance doses of $\mathrm{MgSO}_{4}$}

\begin{tabular}{|c|c|c|c|c|c|c|}
\hline & \multicolumn{2}{|c|}{$\begin{array}{l}\text { What is the total loading } \\
\text { dose of } \mathrm{MgSO}_{4} ?\end{array}$} & \multicolumn{4}{|c|}{$\begin{array}{l}\text { What is the maintenance dose of } \\
\mathrm{MgSO}_{4} \text { in PE/E for intramuscular } \\
\text { injection? }\end{array}$} \\
\hline & $\begin{array}{l}\% \text { Correct } \\
\text { response }\end{array}$ & p-value & $n=379$ & $\%$ Correct response & p-value & $n=379$ \\
\hline \multicolumn{7}{|l|}{ Type of provider } \\
\hline Medical practitioners & 25.7 & \multirow{3}{*}{0.000} & 35 & 8.6 & \multirow{3}{*}{0.000} & 35 \\
\hline Nurses/Midwives & 14.5 & & 200 & 16.0 & & 200 \\
\hline CHEWs, CHOs \& Others & 4.2 & & 144 & 2.8 & & 144 \\
\hline \multicolumn{7}{|l|}{ Type of facility } \\
\hline Tertiary & 12.5 & \multirow{3}{*}{0.000} & 80 & 25.0 & \multirow{3}{*}{0.000} & 80 \\
\hline Secondary & 21.0 & & 124 & 9.7 & & 124 \\
\hline Primary & 4.6 & & 175 & 4.0 & & 175 \\
\hline \multicolumn{7}{|c|}{ Years working in present unit/ward } \\
\hline$\leq 1$ years & 11.8 & \multirow{4}{*}{0.560} & 93 & 10.8 & \multirow{4}{*}{0.377} & 93 \\
\hline$>1-5$ years & 10.8 & & 158 & 12.0 & & 158 \\
\hline$>5$ years & 14.6 & & 89 & 10.1 & & 89 \\
\hline No response & 7.7 & & 39 & 2.6 & & 39 \\
\hline \multicolumn{7}{|c|}{ Received any training on maternal health, FP or child health care } \\
\hline Yes & 11.3 & \multirow{2}{*}{0.049} & 194 & 11.3 & \multirow{2}{*}{0.113} & 194 \\
\hline No & 11.9 & & 185 & 9.2 & & 185 \\
\hline
\end{tabular}

Although $\mathrm{MgSO}_{4}$ toxicity is rare, when it occurs, the universal antidote is calcium gluconate. Only 7 percent of the providers knew to use calcium gluconate as the antidote for $\mathrm{MgSO}_{4}$ toxicity (Figure 8). Almost twothirds of providers did not know an antidote exists.

\section{FIGURE 8 Knowledge of calcium gluconate as antidote to $\mathrm{MgSO}_{4}$ toxicity}

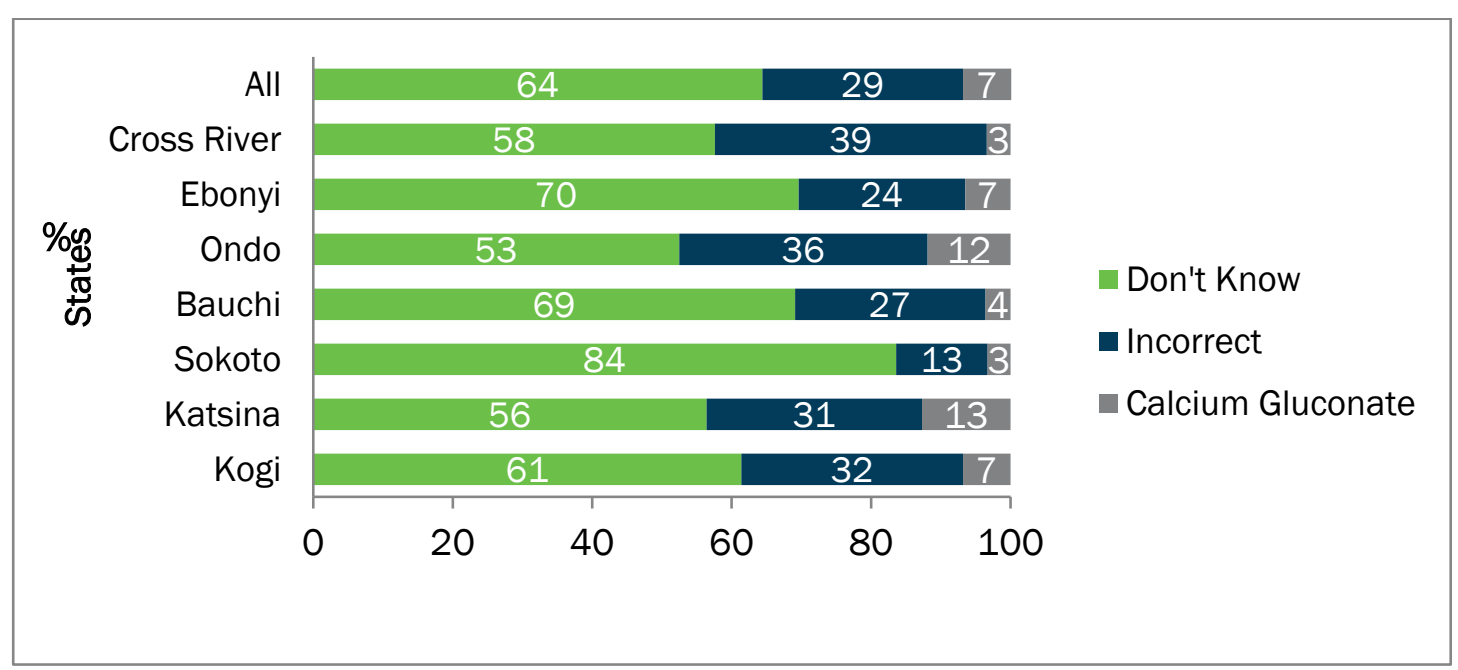


If $\mathrm{MgSO}_{4}$ is administered, providers should monitor patients for clinical evidence of toxicity, which may present as depressed respiratory rate, loss of tendon reflex, or decreased urine output, either in isolation or in any combination of all three. Less than 11 percent of the healthcare providers surveyed mentioned the three potential symptoms to monitor $\mathrm{MgSO}_{4}$ toxicity. As expected, medical officers are more likely to know how to monitor $\mathrm{MgSO}_{4}$ and which drug is used to treat it. Two-thirds of medical practitioners did not know how to monitor for toxicity or know the antidote (Table 9).

\section{TABLE 9 Knowledge of monitoring $\mathrm{MgSO}_{4}$ toxicity}

\begin{tabular}{|c|c|c|c|c|c|c|}
\hline & \multicolumn{2}{|c|}{$\begin{array}{l}\text { Ways to monitor } \\
\mathrm{MgSO}_{4} \text { toxicity }\end{array}$} & \multirow[b]{2}{*}{$n=379$} & \multicolumn{3}{|c|}{$\begin{array}{l}\text { What drug is used for treating } \\
\qquad \mathrm{MgSO}_{4} \text { toxicity? }\end{array}$} \\
\hline & $\begin{array}{l}\% \text { Correct } \\
\text { response }\end{array}$ & p-value & & $\begin{array}{l}\% \text { Correct } \\
\text { response }\end{array}$ & p-value & $n=379$ \\
\hline \multicolumn{7}{|l|}{ Type of provider } \\
\hline Medical practitioner & 31.4 & \multirow{3}{*}{0.000} & 35 & 57.1 & \multirow{3}{*}{0.000} & 35 \\
\hline Nurse/Midwife & 10.0 & & 200 & 38.0 & & 200 \\
\hline CHEW. CHO \& Others & 7.6 & & 144 & 9.0 & & 144 \\
\hline \multicolumn{7}{|l|}{ Type of facility } \\
\hline Tertiary & 18.8 & \multirow{3}{*}{0.046} & 80 & 36.3 & 0.000 & 80 \\
\hline Secondary & 9.7 & & 124 & 46.0 & & 124 \\
\hline Primary & 8.6 & & 175 & 13.1 & & 175 \\
\hline \multicolumn{7}{|c|}{ Years working in present unit/ward } \\
\hline$\leq 1$ years & 14.0 & \multirow{4}{*}{0.103} & 93 & 34.4 & 0.007 & 93 \\
\hline$>1-5$ years & 13.9 & & 158 & 26.6 & & 158 \\
\hline$>5$ years & 5.6 & & 89 & 28.1 & & 89 \\
\hline No response & 5.1 & & 39 & 25.6 & & 39 \\
\hline \multicolumn{7}{|c|}{ Received any training on maternal health, FP or child health care } \\
\hline Yes & 13.9 & \multirow{2}{*}{0.072} & 194 & 33.5 & 0.008 & 194 \\
\hline No & 8.1 & & 185 & 23.8 & & 185 \\
\hline
\end{tabular}

During this landscape analysis, we assessed facilities' readiness to effectively manage PE/E by examining their guidelines, essential tools, and commodities, if they keep $\mathrm{MgSO}_{4}$ in stock, and the concentration of $\mathrm{MgSO}_{4}$ used. Figure 9 shows how facilities in the seven study states generally obtain $\mathrm{MgSO}_{4}$. Overall, 39 percent of facilities asked women with $\mathrm{PE} / \mathrm{E}$ (or their families) to purchase $\mathrm{MgSO}_{4}$ from outside sources, as the drug is not stored routinely at the facilities. However, it may take time to obtain the drug, depending on affordability and proximity to drug stores that stock it. This delay worsens the outcomes for women and their unborn babies. The tendency to ask PE/E patients or their families to purchase $\mathrm{MgSO}_{4}$ was highest in Katsina and Kogi states, but not practiced in Ebonyi. 


\section{FIGURE 9 How facilities obtain $\mathrm{MgSO}_{4}$}

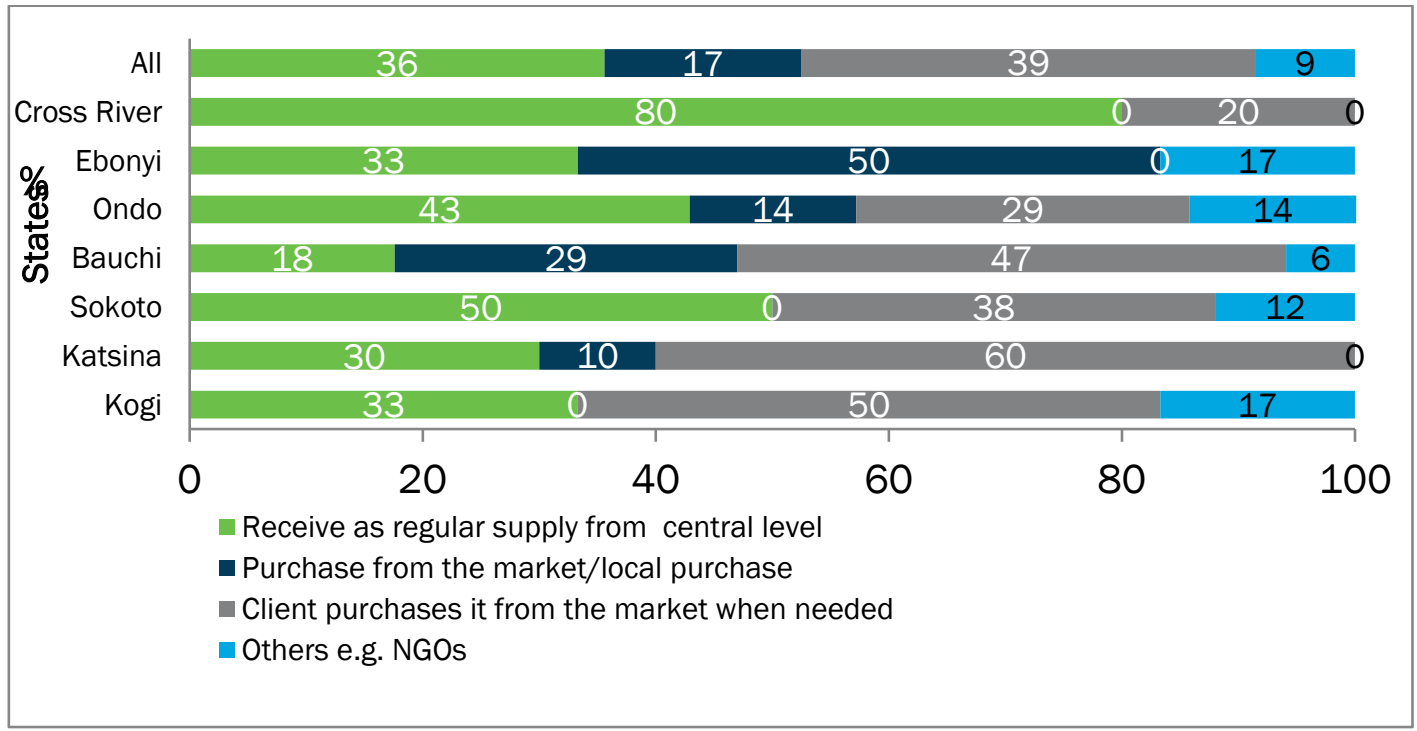

Overall 20 percent of facilities do not use $\mathrm{MgSO}_{4}$, and only 42 percent reported always using $\mathrm{MgSO}_{4}$ as an anticonvulsant (Figure 10). In Ebonyi and Cross River states, 70 percent and 55 percent respectively, of facilities do not use $\mathrm{MgSO}_{4}$ to prevent and treat convulsions.

\section{FIGURE $10 \mathrm{MgSO}_{4}$ use for treating pre-eclampsia or eclampsia}

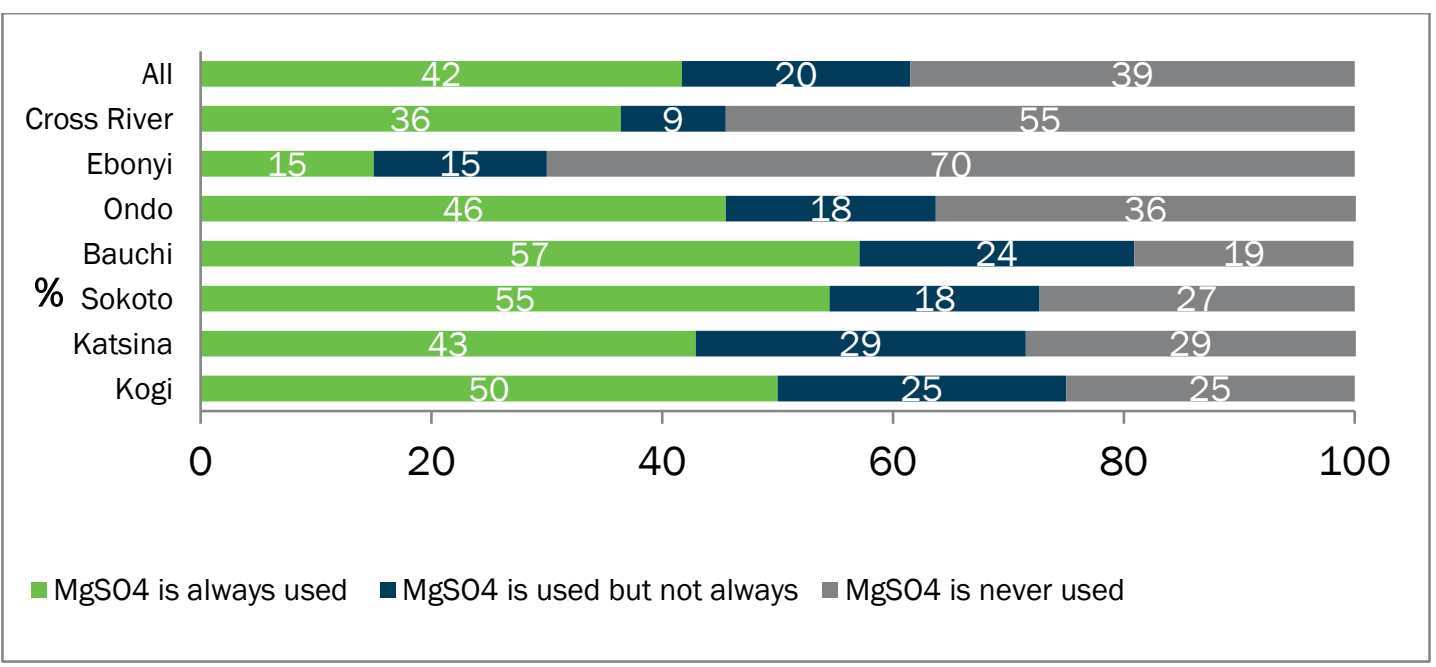


Figure 11 shows the distribution of '20\%' and ' $50 \%$ ' $\mathrm{MgSO}_{4}$ concentrations among the seven study states. Overall, 66 percent of facilities used $50 \%$ solution and only $20 \%$ of the facilities use $20 \%$ solution. Bauchi, Katsina, Kogi, and Sokoto States use the $50 \%$ strength, while Ebonyi State uses the $20 \%$ solution. There is increasing support for a 50\% concentration among the public sector and donors' procurement mechanisms due to the simple preparation required for its administration. Therefore, it is not surprising to find that the $50 \%$ solution dominates the public sector, while both concentrations are found with similar frequencies in states where private procurement is common, such as Ebonyi State.

\section{FIGURE 11 Concentration (\%) of $\mathrm{MgSO}_{4}$ used in facilities}

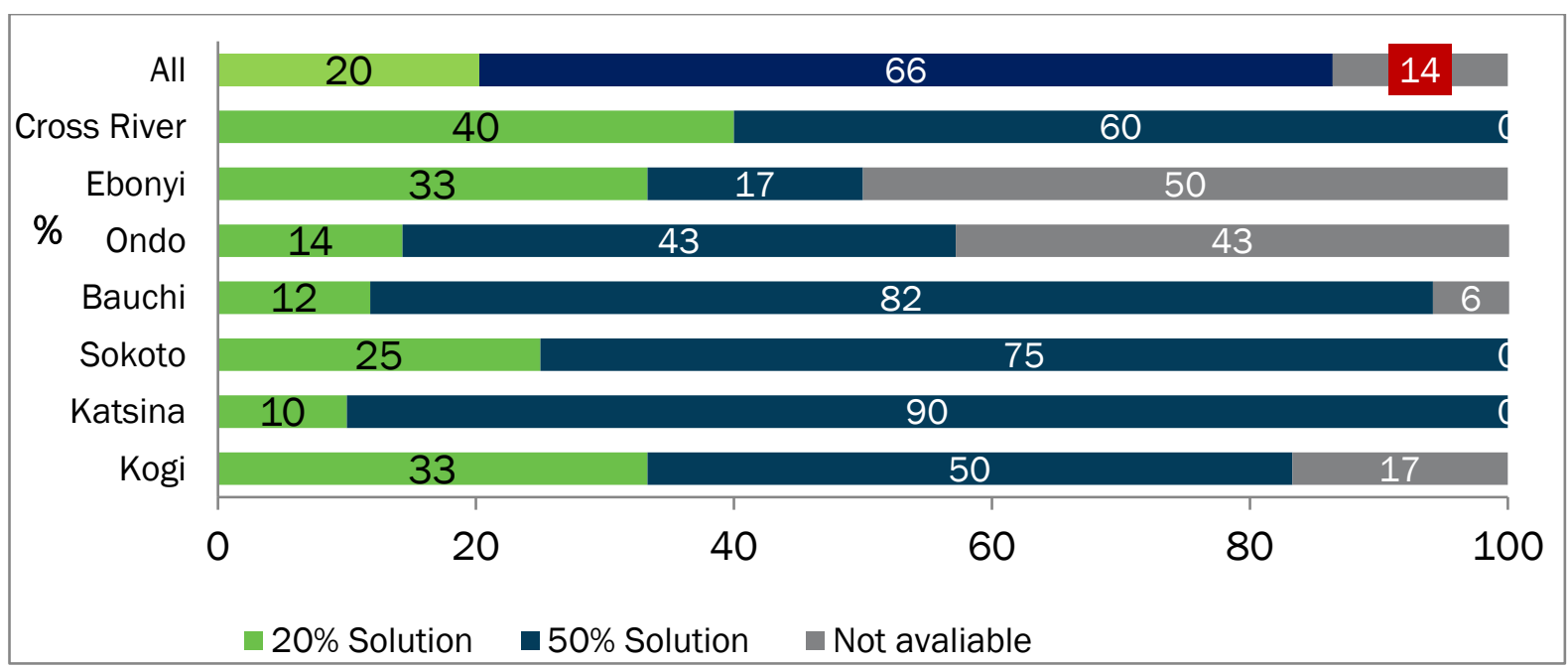




\section{Client Experiences}

Researchers conducted client exit interviews after the ANC consultations to determine pregnant women's perceptions on the quality of care they received and their understanding of the services received. The disaggregated percentages in Table 9 show that while 91 percent of women had their blood pressure measured, when probed further about the services received, only 31 percent of women reported that their healthcare provider informed them of their BP measurement and 32 percent received an explanation of the meaning of high blood pressure. Similarly, while two-thirds of women had their protein checked for urine, a mere 19 percent were given an explanation about why protein in the urine is important to measure (data not shown in the table).

\section{TABLE 9 Proportion of pregnant women receiving specific services and information during ANC consultations by state}

\begin{tabular}{|lccccccccc|} 
State & $\begin{array}{c}\text { Took } \\
\text { weight }\end{array}$ & $\begin{array}{c}\text { BP } \\
\text { check }\end{array}$ & $\begin{array}{c}\text { Performed } \\
\text { abdominal } \\
\text { examination }\end{array}$ & $\begin{array}{c}\text { Checked } \\
\text { for } \\
\text { anemia }\end{array}$ & $\begin{array}{c}\text { Listened } \\
\text { to } \\
\text { baby's } \\
\text { heart } \\
\text { beat }\end{array}$ & $\begin{array}{c}\text { Checked } \\
\text { urine for } \\
\text { protein } \\
\text { and } \\
\text { sugar }\end{array}$ & $\begin{array}{c}\text { Talked } \\
\text { with client } \\
\text { about the } \\
\text { progress } \\
\text { of your } \\
\text { pregnancy }\end{array}$ & $\begin{array}{c}\text { Gave } \\
\text { client } \\
\text { chance } \\
\text { to ask }\end{array}$ & $\begin{array}{c}\text { Number of } \\
\text { women } \\
\text { interviewed }\end{array}$ \\
\hline $\begin{array}{l}\text { Cross } \\
\text { River }\end{array}$ & 100 & 100 & 93 & 40 & 93 & 87 & 87 & 87 & 15 \\
\hline Ebonyi & 100 & 100 & 80 & 50 & 80 & 40 & 50 & 80 & 10 \\
\hline Ondo & 77 & 91 & 68 & 41 & 68 & 59 & 68 & 73 & 22 \\
\hline Kogi & 87 & 80 & 67 & 73 & 67 & 67 & 67 & 60 & 15 \\
\hline Sokoto & 73 & 100 & 95 & 22 & 78 & 60 & 68 & 60 & 37 \\
\hline Katsina & 50 & 63 & 25 & 38 & 25 & 63 & 25 & 25 & 8 \\
\hline Bauchi & 89 & 89 & 93 & 46 & 93 & 82 & 86 & 89 & 28 \\
\hline Total & 82 & 92 & 82 & 41 & 77 & 67 & 70 & 70 & 135 \\
\hline
\end{tabular}

Regardless of demographic and socio-economic status, a number of clients (a third overall) said the providers did not discuss the progress of the pregnancy or give a chance for them to ask questions. This was least likely to happen in Katsina followed by Ondo state. None of the states performed well in all areas. The two weakest components were checking for anemia and checking urine for protein and sugar.

Table 10 presents composite responses of the eight ANC services provided during the current and any ANC consultation by socio economic/demographic status. Overall, less than one-third of women interviewed received all of the ANC services in this visit and one-sixth received all of the services at any ANC visit. 
TABLE 10 Proportion of clients receiving all eight components of ANC by social demographic status (composite score)

\begin{tabular}{|c|c|c|c|c|c|}
\hline & n & $\begin{array}{c}\text { Yes } \\
\%\end{array}$ & p-value & $\begin{array}{c}\text { Yes } \\
\%\end{array}$ & p-value \\
\hline & & \multicolumn{2}{|c|}{$\begin{array}{l}\text { Proportion of clients who } \\
\text { received all } 8 \text { ANC } \\
\text { components during this visit }\end{array}$} & \multicolumn{2}{|c|}{$\begin{array}{c}\text { Proportion of clients who received } \\
\text { all services listed during any ANC } \\
\text { visit }\end{array}$} \\
\hline \multicolumn{6}{|l|}{ Age (years) } \\
\hline$\leq 24$ & 41 & 24.4 & \multirow{2}{*}{0.499} & 17.1 & 0.767 \\
\hline$\geq 25$ & 93 & 30.1 & & 15.1 & \\
\hline \multicolumn{6}{|l|}{ Education } \\
\hline None & 29 & 20.7 & \multirow{4}{*}{0.546} & 13.8 & 0.791 \\
\hline Primary & 12 & 33.3 & & 8.3 & \\
\hline Secondary & 41 & 24.4 & & 19.5 & \\
\hline Higher & 53 & 34.0 & & 15.1 & \\
\hline \multicolumn{6}{|l|}{ Marital status } \\
\hline Married & 130 & 28.5 & \multirow{2}{*}{$1.000 *$} & 13.8 & $0.027^{*}$ \\
\hline Formerly married & 5 & 20.0 & & 60.0 & \\
\hline \multicolumn{6}{|c|}{ Socio-economic status } \\
\hline Low & 50 & 30.0 & \multirow{3}{*}{0.792} & 18.0 & 0.088 \\
\hline Middle & 63 & 25.4 & & 19.0 & \\
\hline High & 22 & 31.8 & & 0.0 & \\
\hline \multicolumn{6}{|l|}{ Religion } \\
\hline Christianity & 60 & 26.7 & \multirow{2}{*}{0.732} & 16.7 & 0.750 \\
\hline Islam & 75 & 29.3 & & 14.7 & \\
\hline Total & 135 & 28.1 & & 15.6 & \\
\hline
\end{tabular}

Cutting across women of all demographic and socio-economic status, and despite the large gap in the content and quality of ANC they received, most women said they would go back to the same facilities for future care and expressed satisfaction with the care they received. Only 12 percent of women said that they would not return to the same health facility; the reasons cited for not returning were that the facility was too far, a lack of money to pay for services, a lack of supplies/medicine at facility, not enough providers at the facility, providers were unfriendly, and poor services at the facility. 


\section{COMMUNITY-LEVEL PERCEPTIONS}

Qualitative interviews were conducted with PE/E survivors, community stakeholders and families affected by $\mathrm{PE} / \mathrm{E}$ on their understanding of $\mathrm{PE} / \mathrm{E}$ and care seeking pathways.

All groups (men and women; rural and urban areas) described similar health challenges for pregnant women, these include malaria, typhoid, cough, stomach ache, and high blood pressure. There is some confusion regarding the diagnosis of pre-eclampsia and malaria. Headache during pregnancy is more often assumed to be a symptom of malaria. The signs and symptoms associated with PE/E are sometimes attributed to excessive drinking of liquids and over exposure to cold weather.

Respondents also had similar perceptions as to the cause of high blood pressure. Some people believe evil spirits (e.g., demons, witches, and ancestors) cause seizures. Rural community men perceive that high blood pressure is caused by engaging in 'strenuous' or 'tedious' activities and not eating a balanced diet. 'Over thinking' and anxiety were also deemed to be causes of high blood pressure in pregnancy.

"First pregnancies always lead to high blood pressure because some women listen to stories of pregnancy worries." Male FGD

Misconceptions, belief in myths, and mistrust between communities and health providers negatively influence care seeking behaviors for PE/E. Reasons given why women do not seek care at facilities arefear of death, lack of facilities, lack of qualified providers, and disrespectful providers. Overall, men appear to encourage their wives to go to ANC and to hospital to deliver, but some mothers-in-law favor herbalists and prayer as the first line of 'health seeking' before going to the hospital. Participants described using herbs, incisions, and prayers. Two conflicting quotes are outlined below:

"In our community, people think doctors can't solve the problem, so they prefer the herbalist." Community stakeholder

"It is better to go to hospital than native because if the problem does not go, the person will die." Male FGD

When asked what interventions might improve care for pregnant women with $\mathrm{PE} / \mathrm{E}$, suggestions included house to house teaching, community seminars and public enlightenment through radio, fliers, and church notifications.

\section{EXPERIENCES OF SURVIVORS OF PE/E}

Interviews with survivors documented their care-seeking pathways, including their experience with PE/E, the availability and accessibility of essential services and commodities, the outcome of the pregnancy for the mother and her child. The women interviewed were similar in age, age at marriage, age at first pregnancy, and education levels. Majority of respondents attend ANC very late; or at the tail end of the second trimester except in Kogi State where the respondents reported attending ANC during the first trimester or early second trimester. However, more than half started ANC when they begin to notice some pregnancy-related problems like swollen legs or face or a severe headache. Most women attended public health facilities. Responses also show that during ANC, BP is mostly measured and urine is tested but results are not often made known except when a complication is about to occur. Information regarding possible pregnancy-related problems is not properly communicated during ANC consultations. 
In all instances, $\mathrm{MgSO}_{4}$ was not stocked at the health facilities, and so the women purchased the drug from external sources such as pharmacies and drug shops.

\section{Case study}

A 40-year-old woman with a postgraduate degree was married at age 29 and became pregnant at age 33. After three pregnancies, she has two living children. She lives within twenty minutes of a health facility. During the second pregnancy, she booked herself at a nurse-attended health facility and attended 12 ANC visits. She developed eclampsia and received $\mathrm{MgSO}_{4}$, but eventually delivered a stillborn baby. She purchased the $\mathrm{MgSO}_{4}$ from the outside pharmacy shop, and said the drug was easily available and affordable.

"I lost the baby. It took a while before my blood pressure eventually normalized. The same headache was there, discomfort, and swelling of the legs was there for quite a long time after the baby died." -Survivor

Younger women were also interviewed. They differed from the women discussed above not only in age, but also in education level and socio-economic status.

"I am 17 years old, and I was married two years ago. This is my first pregnancy and it is nine months. I never attend ANC before, but I came to the hospital when I had a severe headache for over two weeks, I became dizzy and fell down. I went to a hospital...I did not know what happened, but later the doctor told me that my BP was 250/150... I am OK now, but lost my baby." - Survivor

"I only come to the hospital when am critically ill. I delivered twins, but I lost the first one. Drugs are very expensive, and my husband cannot afford to buy them and my relatives don't have anything. They said I need more blood but I did not get it yet. I am very weak, and have no food and no money to buy food." - Survivor

"Or you are seeking for a particular sex, every time, day and night, you will be thinking 'I am going to have male child or female child,' such a thing can lead to high blood pressure." Survivor 


\section{Discussion}

This landscape analysis set out to understand the existing and ongoing research, as well as the policy and programmatic support for PE/E in Nigeria. It also aimed to analyze the gaps in facilities' and providers' capacity to prevent, detect, and manage PE/E; assess community awareness, beliefs, and experiences around $\mathrm{PE} / \mathrm{E}$; and determine the gaps and priority areas for research and programs for improving access to prevention and treatment of $\mathrm{PE} / \mathrm{E}$.

There are national policies that enable task shifting of essential $\mathrm{MCH}$ interventions from nurses/midwives to $\mathrm{CHEWs} / \mathrm{CHOs}$, specifically empowering $\mathrm{CHEWs}$ to detect and administer a loading of $\mathrm{MgSO}_{4}$ to women with PE/E (among other pregnancy complications) before referral (Federal Ministry of Health, 2014), but, few policy makers at state level were aware of these national policies. For successful implementation and scale up, all existing policy documents at the national and state levels should be communicated down to local stakeholders for proper utilization. More than 90 percent of health providers surveyed were nurses/midwives or CHEWs/CHOs working at primary and secondary facilities and many at PHC facilities are unaware of policy changes that empower them to administer a loading dose of $\mathrm{MgSO}_{4}$ before referring patients.

Despite the evidence that low-dose aspirin, started between 12 and 20 weeks gestation in women with known risk factors for pre-eclampsia, significantly reduces the incidence of PE (World Health Organization, 2011), it appears that this preventative strategy has not yet been adopted by Nigeria. It is therefore not surprising that more than four-fifths of healthcare providers do not routinely assess for risk factors, let alone deploy effective preventive measures. While more health providers than expected were aware of the prophylactic role of aspirin in PE (21\% overall, and $33 \%$ in Ebonyi), the actual administration is disproportionately low. Additionally, few states are offering calcium to women as prophylaxis.

Similarly, little is being done to manage hypertension in pregnant women, as most providers do not give anti-hypertensives for women with hypertensive disorders during pregnancy. This is possibly a result of their inability to classify, and determine the severity of the hypertensive disorders in pregnancy. In Nigeria, antihypertensives for the treatment of mild to moderate hypertension (aldomet and nifedipine) and severe hypertension (hydralazine) are cheap and easily obtainable. They should be routinely available in maternity emergency trays in most facilities, and if not, can be obtained from external sources. Therefore, it is imperative that future interventions targeting health providers, especially at primary and secondary facilities, include training on suitable anti-hypertensives for pregnant women with PE/E.

For effective management of $\mathrm{PE} / \mathrm{E}$, health providers also need training and mentoring on how to use $\mathrm{MgSO}_{4}$. With few providers understanding the loading and maintenance doses of $\mathrm{MgSO}_{4}$ for managing $\mathrm{PE} / \mathrm{E}$, it is not surprising that these pregnancy complications account for more maternal deaths than any other cause, including postpartum hemorrhage (Oladapo 2015).

While ensuring that healthcare providers are adequately trained to administer $\mathrm{MgSO}_{4}$ at the right time and with the proper doses, they also need to know the warning signs for $\mathrm{MgSO}_{4}$ toxicity and the proven antidote, calcium gluconate. Currently, this knowledge is lacking, as 64 percent of providers were unaware of possible toxicity and how to treat it. 
It is common for maternal health commodities to be unavailable when needed. For example, up to 39 percent of facilities surveyed don't keep $\mathrm{MgSO}_{4}$ on site but ask patients to purchase the drug from outside sources. In most cases, patients cannot afford the drugs or are not close enough to health facilities. Similarly, the necessary guidelines, job aids, working tools, and equipment are lacking in many facilities. Policy makers and program managers should make sure that facilities are supported with the required tools and equipment, as well as guidelines in order to help them manage PE/E and improve the overall quality of care. This includes providers assessing medical history or educating women on signs and symptoms of pregnancy-related complications.

Care seeking pathways by women suffering from PE/E are similar to other maternal complications especially in areas where women have little agency to make decisions about seeking care and having to rely on other people to make those decisions. Challenges around the recognition of PE exist due to the similar symptoms to malaria (headache/blurred vision) that may delay women seeking care. These persistent community misconceptions around the causes and outcomes of PE/E constitute threats to the prevention, early detection, and treatment of PE/E. Despite some awareness creation activities and community mobilization efforts, many community members still ascribe spiritual and social factors as causes for PE/E. 


\section{Conclusion and recommendations}

In order to improve the health outcomes for women with PE/E in Nigeria, the following cross-cutting activties are recommended.

\section{CROSS-CUTTING RECOMMENDATIONS}

1. Hold meetings to discuss the current policy, strategy and guidelines on prevention and detection of $\mathrm{PE} / \mathrm{E}$. The national reproductive health coordinating committee convene a task force to work on this issue led by joint chairpersons from SOGON, FMoH and the Nursing/Midwifery Association. This taskforce would also look into streamlining procurement of $\mathrm{MgSO}_{4}$ and other maternal health commodities and drugs (anti-hypertensives, oxytocin, antibiotics, others).

2. Work with federal and state governments to ensure that quality $\mathrm{MgSO}_{4}$ is procured systematically.

3. National 'task force' to review evidence on aspirin/calcium prophylaxis, including the cost of introducing /ensuring consistent supply of aspirin and or calcium supplements. If task force agrees to go forward with prophylaxis approach, guidelines need to be updated prior to stepwise introduction of aspirin and calcium prophylaxis.

4. Emphasis should be placed on primary and secondary facilities that treat more than $90 \%$ of pregnant women. Within these platforms, nurses, midwives, CHEWs, and $\mathrm{CHOs}$ need training and mentoring programs. All maternity care providers at the primary and secondary facilities should know how to triage women at risk of developing PE.

5. Improve the quality of ANC services; providers should conduct routine assessments (specifically BP measurement and urine testing for proteinuria) and advise pregnant women of key danger signs during ANC consultations.

6. Provide training on the management of premature babies that may inadvertently arise as an unwanted consequence of PE/E treatment.

7. Engage with local communities to dispel misperceptions around the risks and consequences of $\mathrm{PE} / \mathrm{E}$ is critical for effective interventions.

8. Communicate national maternal health policies to health providers at primary and secondary facilities.

9. Conduct implementation research to guide the development of highly-effective, low-cost interventions for the prevention and management of PE/E at different levels of the health system:

a. Test feasibility of adding anti-hypertensives at PHC level;

b. Improve quality of ANC; and

c. Community awareness strategies - media, women's groups, champions, among others.

10. Dissemination of findings at state level through research updates for each individual state and meetings. 


\section{References}

1. Ameh CA, Tukur J, Ekechi Cl. Monitoring Severe Pre-Eclampsia and Eclampsia Treatment in Resource Poor Countries: Skilled Birth Attendant Perception of a New Treatment and Monitoring Chart (LIVKAN Chart). Maternal and Child Health Journal 2012.

2. Ezugwu, E., Agu, P., Nwoke, M., \& Ezugwu, F. (2014). Reducing maternal deaths in a low resource setting in Nigeria. Nigerian Journal of Clinical Practice, 17(1), 62-66.

3. Federal Ministry of Health. Country implementation plan for prioritized life-saving commodities for women and children. 2013; Abuja, Nigeria.

4. Federal Ministry of Health. Task-shifting and task-sharing policy for essential health care services in Nigeria. August, 2014; Abuja, Nigeria.

5. Hofmeyr GJ, Lawrie TA, Atallah AN, Duley L \& Torloni MR. Calcium supplementation during pregnancy for preventing hypertensive disorders and related problems. 2014 Cochrane database Syst Rev. 10.1002/14651858.

6. Ishaku, SM. Ahonsi B, Tuku Jr, Oginni A. Attrition from care after the critical phase of severe preeclampsia and eclampsia: Insights from an intervention with magnesium sulphate in a primary care setting in northern Nigeria. 2013 SciRes.

7. Igwegbe AO, Eleje GU, Ugboaja JO, Ofiaeli RO. Improving maternal mortality at a university teaching hospital in Nnewi, Nigeria. Int J Gynaecol Obstet. 2012.

8. Lalonde, AB, and R Grellier. 2012. "FIGO Saving Mothers and Newborns Initiative 2006-2011." International Journal of Gynecology \& Obstetrics.

http://www.sciencedirect.com/science/article/pii/S0020729212001518.

9. National Institute for Health and Care excellence. Hypertension in pregnancy: The management of hypertensive disorders during pregnancy. 2010. Retrieved September 2015 from https://www.nice.org.uk/guidance/cg107/chapter/guidance\#management-of-pregnancy-withpre-eclampsia.

10. Okonofua, FE, and RN Ogu. 2013. "Training Health Workers for Magnesium Sulfate Use Reduces Case Fatality from Eclampsia: Results from a Multicenter Trial.” Acta Obstetricia et Gynecologica Scandinavica. http://onlinelibrary.wiley.com/doi/10.1111/aogs.12135/full.

11. Oladapo OT, Adetoro O0, Ekele BA, Chama C, Etuk SJ, Aboyeji AP et al. Nigeria near-miss and maternal death surveillance network. When getting there is enough: a nationwide cross-sectional study of 998 maternal deaths and 1451 near-misses in public tertiary hospitals in a low-income country. 2015 BJOG.

12. Osungbade, K., Oginni, S., Olumide, A. K. O., Oginni, S., \& Olumide, A. Content of antenatal care services in secondary health care facilities in Nigeria: implication for quality of maternal health care. 2008. International Journal for Quality in Health Care.

13. Tukur, J, B Ahonsi, and SM Ishaku. 2013. "Maternal and Fetal Outcomes after Introduction of Magnesium Sulphate for Treatment of Preeclampsia and Eclampsia in Selected Secondary Facilities: A Low-Cost." Maternal and Child .... http://link.springer.com/article/10.1007/s10995012-1105-9.

14. World Health Organization. WHO Recommendations for prevention and treatment of preeclampsia and eclampsia. 2011. 20 Avenue Appia, 1211 Geneva 27, Switzerland; ISBN 978924 1548335.

15. World Health Organization. Strategies toward ending preventable maternal mortality (SPMM) 2015. World Health Organization, 20 Avenue Appia, 1211 Geneva 27, Switzerland. ISBN 97892 41508483.

\section{POPULATION}

